\title{
İŞ HUKUKUNDA GENETİK AYRIMCILIK YASAĞI
}

DOI: https://doi.org/10.33717/deuhfd.793080

\author{
Dr. Ö̆rr. Üyesi Yasemin TAŞDEMIR*
}

\begin{abstract}
$\ddot{\mathbf{O z}}$
Genetik bilimindeki hızlı ilerleyiş, özellikle să̆lık açısından insanlı̆̆a olumlu katkılar sunmaktadır. Özellikle genetik bilimi sayesinde kişinin muhtemel sağliğıyla ilgili bilgi edinebilme imkanı her geçen gün dikkat çekmekte ve fakat genetik testler yoluyla elde edilen söz konusu içerikteki genetik bilgilere ulaşımın kolaylaşması, genetik bilginin kötüye kullanımına ilişkin örnekleri de çoğalmaktadır. İş Hukuku alanında genetik bilginin kötüye kullanılmasının yolu, genetik bilgi vasitasıyla işçi adaylarına ve işçilere farklı muamelede bulunulmasıdır. Bu durumun önüne geçilmesi bakımından İs Hukukunda genetik ayrımcllık yasağı, önemli bir kural olarak zikredilmektedir. Her ne kadar halihazırda yasal düzenlemeleri incelediğimiz zaman İş Hukukunda genetik ayrımcılığın yasak olduğu sonucuna ulaşsak da konu ile ilgili ayrı bir yasal düzenlemenin gerekli olduğu kanaatine vardığımız çalışmamızda öncelikle genetik bilgi, genetik test kavramları açıklı̆̆a kavuşturulmuştur. Genetik ayrımcılık kavramı tanımlandıktan sonra genetik ayrımcılığın $\dot{I}_{S}$ Hukukundaki örneklerine değinilerek konu ile ilgili uluslararası düzenlemeler sıralanmıştır. İş Hukukunda genetik ayrımcılık yasă̆l ile ilgili doktrinde sıkça değinilen ABD’nin Genetik Bilgiye Dayalı Ayrımcılık Yasağı Kanunu incelendikten sonra konu, Türk Hukuku bakımından ele alınmıştır.
\end{abstract}

\section{Anahtar Kelimeler}

Genetik bilgi, genetik test, genetik ayrumcıllk, kişisel veri, genetik ayrımcılık yasă̆ı, iş hukukunda genetik ayrımcılık

Sakarya Üniversitesi Hukuk Fakültesi, İş ve Sosyal Güvenlik Hukuku Anabilim Dalı Öğretim Üyesi (e-posta: ybasmanav@sakarya.edu.tr) ORCID: https://orcid.org/00000001-9334-5232 (Makalenin Geliş Tarihi: 02.07.2020) (Makale Gönderilme Tarihi: 20.07.2020/Makale Kabul Tarihi: 29.07.2020) 


\title{
PROHIBITION OF GENETIC DISCRIMINATION IN LABOUR LAW
}

\begin{abstract}
Major developments in genetic science provide positive contributions, especially to human health. While the possibility to learn more about human health increases, genetic science also eases to achieve genetic data obtained by genetic tests and leads to misusage of this genetic data. Misusage of genetic data in labour law comes up as discrimination based on genetic data. To avoid this outcome, the prohibition of genetic discrimination is regulated in labour law. Even though the existing regulations prohibit genetic discrimination, in this study the necessity of specific regulations in this regard is established and the terms of genetic data and genetic test are clarified. Upon defining the term "genetic discrimination", examples from labour law and international regulations are introduced. Genetic Information Nondiscrimination Act of USA, which is referred quite often in this regard, is analyzed and the issue is addressed with regards to Turkish Law.
\end{abstract}

\section{Keywords}

Genetic data, genetic test, genetic discrimination, personal data, the prohibition of genetic discrimination, genetic discrimination in labour law 


\section{GİRIŞ}

Bilimsel teknoloji şaşırtıcı bir hızla ilerlemekte ve insanlığa her geçen gün yeni bilgi zenginliği sağlamaktadır. Özellikle yeni genetik teknolojiler, insan sağlığı alanında büyük ilerlemeler kaydetmekte ve genetik temelli hastalıkların tanımlanması, önlenmesi ve tedavi edilmesinde araçlar temin etmektedir ${ }^{1}$.

Genetik, kalıtım bilimidir ve boy veya göz rengi gibi fiziksel özelliklerden kalp hastalığı ve belirli kanser türleri gibi karmaşık hastalık duyarlılıklarına kadar belirli özelliklerin ebeveynlerden çocuklara nasıl aktarıldığının araştırılmasıdır ${ }^{2}$. Genetik, genlere ve bunların hastalık ve kalıtım üzerindeki etkilerine odaklanır ve özellikle tıbbi genetik, insan vücudundaki hastalık ve genler arasındaki etkileşimi daha iyi anlamakla ilgilenir ${ }^{3}$.

Son y1llarda genetik biliminin ürünü olan genetik testler, daha erişilebilir ve yaygın hale gelmiş bulunmaktadır. Kalıtsal hastalıkların teşhis edilmesi ve gelecekteki hastalıkların tespit edilme imkanı sağlandığı için insanların, genetik testlere yönelik tutumu genellikle olumludur ${ }^{4}$. Genetik bilimi ve teknolojisinin hastalıkları önlemek ve tedavi etmek için büyük bir potansiyel sergilediği genel olarak kabul edilmektedir ${ }^{5}$. Bununla birlikte yetkisiz erişim, ifşa ve bu tür bilgilerin kullanımı nedeniyle ilgili üçüncü tarafların genetik mahremiyetinin potansiyel ihlali ile ilgili endişeler ve ek olarak, genetik bilginin bir kişiye karşı ayrımcılık yapmak için kötüye kullanılması korkusu da hızla artmaktadır ${ }^{6}$.

Genetik bilginin kötüye kullanılması bir başka deyişle genetik ayrımcılığa ilişkin korku, özellikle Sigorta Hukuku ve İş Hukuku alanında ortaya

Gardner-Hopkins, James Desmond K: "Unemployable Genes: Genetic Discrimination in the Workplace", Auckland University Law Review, Cilt 9, Say1 2, 2001, s. 435.

2 Paor, Aisling de/Lowndes, Noel: "Tracing The History, Evolution and Future Orientation of Genetic Science and Technology", Genetic Discrimination Transatlantic Perspectives On The Case For a European-Level Legal Response, (Ed. Gerard Quinn, Aisling de Paor and Peter Blanck), Routledge, New York, 2015, s. 11.

Paor/Lowndes, s. 11.

Paor, Aisling de/Ferri, Delia: "Regulating Genetic Discrimination in the European Union”, European Journal of Law Reform, Cilt 17, Say1 1, 2015, s. 14.

Paor/Ferri, s. 14.

Paor/Ferri, s. 14-15; Aynı yönde Kim, J. Rosel/Salman, Shahad/Joly, Yann: "The Use of Genetic İnformation Outside of The Therapeutic Health Relationship: An İnternational Perspective", Genetic Discrimination Transatlantic Perspectives On The Case For a European-Level Legal Response, (Ed. Gerard Quinn, Aisling de Paor and Peter Blanck), Routledge, New York, 2015, s. 68. 
çıkmaktadır. Bu sebeple uluslararası ve ulusal düzeyde düzenlemeler yürürlüğe girmiştir.

İş Hukukunda genetik ayrımcılığın incelenmesinin amaçlandığı çalışmamızda, öncelikle genetik bilgi ve genetik ayrımcılık kavramına değinilmiş ve daha sonra, genetik ayrımcılığın İş Hukukundaki etkilerine örnekler verilmiştir. Diğer bölümde ilk olarak genetik ayrımcılık yasağı ile ilgili uluslararası düzenlemelerden bahsedilmiş, ardından konu ile ilgili Amerika Birleşik Devletlerindeki yasal düzenleme olan ve konu bakımından önem arz eden Genetik Bilgiye Dayalı Ayrımcılık Yasağı Kanunu ${ }^{7}$ - Genetic Information Nondiscrimination Act of 2008 (GINA) ele alınmıştır. Çalışmamızın son bölümünde ise genetik ayrımcılık yasağının Türk Hukukundaki durumu hakkında açıklamalarda bulunulmuştur.

\section{GENETIK BİLGi}

\section{A. Kavramlar}

Eski çağlardan beri insanlık, hem bitkilerin hem de hayvanların üremesinde genetikten yararlanmaktadır. Bununla birlikte, modern anlamda genetik biliminin 19. yüzyılın ortalarında Avusturyalı keşiş Gregor Mendel'in çalışmasıyla başladığı düşünülmektedir ${ }^{8}$. Mendel, kalıtım sürecini ortaya çıkarmaya çalışmış ve organizmaların, şimdi gen olarak adlandırılan kalıtım birimleri aracılığıyla karakteristiklerini miras aldıklarını gözlemlemiştir?'.

İlk genetik keşiflerin ardından, 1953'te Crick ve Watson tarafindan deoksiribonükleik asidin (DNA) çift sarmal yapısı keşfedilmiş ve bu sayede genlerin nasıl çoğaltılabileceği bilgisine ulaşılmışıtır ${ }^{10}$. Belirtilen gelişmeler,

7 Genetic Information Nondiscrimination Act of 2008, Şen tarafindan "Genetik Bilgiye Dayalı Eşit Davranma Yasası" olarak, Gürsel tarafindan "Genetik Bilgilere Dayalı Ayrımcılığa Karşı Kanun" olarak çevrilmiştir. Bkz. Şen, Murat: "Gen Analizlerinin İş Hukuku Alanında Kullanımı”, Marmara Üniversitesi Hukuk Fakültesi Hukuk Araştırmaları Dergisi, Cilt I, Sayı 1, 2012, s. 139; Gürsel, İlke: İş̧̧inin Kişisel Verilerinin Korunması Hakk1, Adalet Yayınevi, Ankara, 2016, s. 340.

$8 \quad$ Paor/Lowndes, s. 12; Aynı yönde Küzeci, Elif: "Genetik Ayrımcılık Yasağı, Yeditepe Üniversitesi Hukuk Fakültesi Dergisi, Cilt XV, Sayı 1, 2018, s. 93.

9 Paor/Lowndes, s. 12; Müteakip önemli genetik keşifler yirminci yüzyıl boyunca yapılmıştır. 1910'da Thomas Morgan'ın meyve sinekleri üzerine yaptığı araştırmalar, gen ve kromozom arasındaki ilişkiyi keşfetti. Morgan'ın çalışmalarında ayrıca, sineklerde rastgele mutasyonların ortaya çıktığı sonucuna varılarak aynı durumun insan genlerinde de olması gerektiği düşüncesi ileri sürüldü. Morgan ile çalışan Alfred Sturtevant da 1913 yılında bir kromozomun ilk defa haritasını çıkardı, Paor/Lowndes, s. 13.

Paor/Lowndes, s. 13. 
genetik testlerin gelişimini hızlandırdığı gibi ayrıca İnsan Genom Projesinin de (Human Genom Project) ${ }^{11}$ temelini atmıştır ${ }^{12}$.

Gen, kalıtsal bilgilerin bir hücrede depolanmasından ve aktarılmasından sorumlu kimyasal olan DNA'nın parçası olarak tanımlanabilirr ${ }^{13}$. Tüm genetik bilgilerin temel taşıyıcısı DNA olmakla birlikte, kalıtımın temel fiziksel ve fonksiyonel birimleri genlerdir. Genler, amino asitlerin birleştiği sırayı ve dolayısıyla üretilen proteinlerin şeklini ve karakterini belirleyen bilgiyi içeren DNA bölümleridir. Bu bilgi de hücrelerin şeklini, karakterini ve dolay1sıyla kişinin bedeninin şeklini, karakterini belirler ${ }^{14}$. Gen en küçük kalıtsal birimi, genom ise bir canlının vücudundaki genlerin toplamını bir başka deyişle bir organizmanın genetik bilgisinin tamamını ifade eder ve bu doğrultuda insan genomu terimi, insan genetik materyalinin tamamını adlandırmak üzere kullanilır ${ }^{15}$.

11 1988'de başlatılan İnsan Genom Projesi (HGP), tüm insan genomunu haritalamayı amaçlayan uluslararası bir araştırma projesidir. Bu projenin başlatılmasında hastalıktan sorumlu genleri ve bu genlerin hastalıkları nasıl tetiklediğini belirlemek, ek olarak hastalıkla ilgili gecikme yaşamadan hastalığın başlangıcını önleme düşüncesi yatmaktadır, Gardner-Hopkins, s. 436; HGP'nin başlangıcı, insanlık tarihinde önemli bir gelişmedir ve bu başlangıç "genomik çağı" müjdelemiştir. Amerika Birleşik Devletleri Enerji Bakanlığı ve Ulusal Sağlık Enstitüleri, İngiltere, Japonya, Fransa, Almanya, Çin ve diğer ortakların katılımıyla HGP koordine edildi. HGP'nin birincil hedefi, insan DNA'sındaki yaklaşık 20.000-25.000 genin tümünü tanımlamak ve insan DNA'sını oluşturan 3 milyar kimyasal baz çiftinin dizilerini belirlemekti, Ajunwa, Ifeoma: "Genetic Data and Civil Rights", Harvard Civil Rights-Civil Liberties Law Review, Cilt 5, Sayı 1, 2016, s. 85; Nemeth, Patricia/Bonnette, Terry W.: "Genetic Discrimination in Employment", Michigan Bar Journal, January 2009, s. 43; HGP ile insan genomunda 25.000 genin kodlandığı belirlenmiştir. İnsan Genom Projesinden elde edilen veriler DNA bilgisinin \%99'undan fazlasının tüm insanlar için ortak olduğunu ortaya koymuştur, Genetik Terimler Sözlüğ̈̈, http://www.thd.org.tr/thdData/Books/723/genetik-terimler-sozlugu. pdf, (02.04.2020), s. 3; HGP hakkında bkz. Smith, George P. II/Burns, Thaddeus J.: "Genetic Determinism or Genetic Discrimination", Journal of Contemporary Health Law and Policy, Cilt 11, Say1 1, 1994, s. 29 vd; Rojas, Hugo: "Labor Law And Genetic Discrimination in Chile", Florida Journal of International Law, Cilt 16, Say1 3, 2004, s. 563 vd; Kim, Pauline T: "Genetic Discrimination, Genetic Privacy: Rethinking Employee Protections for a Brave New Workplace", Northwestern University Law Review, Cilt 96, Say1 4, 2002, s. 1497 vd.

Paor/Lowndes, s. 13; Bu keşif genetik bilimine ilgiyi hızlandırmıştır. Ayrıca birçok hastalığın temelini daha iyi anlamayı vaat ettiği için 1962 'de Nobel Tip veya Fizyoloji Ödülü'nün hem Watson hem de Crick'e verilmesini sağlamıştır, Paor/Lowndes, s. 13.

Paor/Lowndes, s. 14.

Gardner-Hopkins, s. 436.

Küzeci, s. 93-94; Gardner-Hopkins, s. 436; Genetik Terimler Sözlüğü, s. 20. 
DNA kodunun analiz edilmesi ve İnsan Genom Projesinin tamamlanması ile birlikte insan doğasına ilişkin yeni ve önemli bilgiler ortaya çıkmış ve genetik testler soybağı ve adli amaçlar gibi çeşitli alanlarda kullanılmaya başlamıştır ${ }^{16}$.

Kavram karışıklığ 1 yaşanmaması adına öncelikle genetik bilgi ve genetik test kavramlarının açıklığa kavuşturulması gerekmektedir. Her iki kavram da GINA'da tanımlanmıştır. Buna göre, herhangi bir bireyin genetik testleri, bir bireyin aile üyelerinin genetik testleri ve bir bireyin aile üyelerinde bir hastalık veya rahatsızlığın ortaya çıkması genetik bilgidir (m. 201/4-A). Düzenlemenin devamında "Aile üyesi” kavramı da tanımlanmıştır. Buna göre aile üyesi, bir bireyin birinci derece, ikinci derece, üçüncü derece veya dördüncü derece akrabası olan herhangi bir diğer bireydir. (m. 201/3-B). Genetik bilgi kavramı, herhangi bir bireyin cinsiyeti veya yaşı hakkında bilgi içermemelidir (m. 201/4-C).

Genetik bilgi ile tezahür eden hastalık kastedilmemektedir. Örneğin bir kişinin kolon kanserine olan yatkınlığını gösteren HNPCC (Hereditary Nonpolyposis Colorectal Cancer) testinin pozitif çıkması bir genetik bilgidir; fakat kolonoskopi sırasında keşfedilen bir polip, semptom olduğu için genetik bilgi değildir ${ }^{17}$. Bununla birlikte tezahür eden hastalık ile ilgili bilgiler de genel olarak ayrımcılık yasağına ilişkin düzenlemelere tabidir ${ }^{18}$. Genetik bilgi ile tezahür eden hastalık kavramlarının ayırt edilmesi çok kolay değildir. Bu ayrımın iyi yapılmaması durumunda, semptomları büyük bir yaşam aktivitesini önemli ölçüde sınırlamayan bir işçinin ayrımcılığa maruz kalması örneğinde olduğu gibi İş Hukuku alanında mağduriyet ortaya çıkabilir $^{19}$.

Genetik test ise genotipleri, mutasyonları veya kromozomal değişiklikleri tespit eden insan DNA, RNA, kromozomlar, proteinler veya metabolitlerin analizi anlamına gelmektedir (m. 201/7-A).

Doktrinde genetik test, 'genetik bir bozuklukla ilişkili olması muhtemel bir değişikliği tespit etmek veya hariç tutmak için belirli bir genin, ürünün veya fonksiyonunun veya diğer DNA ve kromozom analizinin çözümlen-

Küzeci, s. 94.

Prince, Anya/Waterstone, Michael: "The Genetic Information Nondiscrimination Act (GINA) 2008", Genetic Discrimination Transatlantic Perspectives On The Case For a European-Level Legal Response, (Ed. Gerard Quinn, Aisling de Paor and Peter Blanck), Routledge, New York, 2015, s. 118.

Ajunwa, s. 94.

Prince/Waterstone, s. 119.
} 
mesi’ olarak tanımlanmıştır ${ }^{20}$. Başka bir deyişle, genetik test (veya tarama), bir bireyin genetik bir kusur veya kanser, alzheimer gibi bazı hastalık türlerini geliştirme veya aktarmaya genetik yatkınlığı olup olmadığını belirlemek için bireyin genetik yapısını tarama işlemidir ${ }^{21}$.

Genetik testte, ilgili kişiden hücre alınır. Genellikle kullanılan hücreler kandan, tükürükten, yanağın içinden veya başka herhangi bir insan dokusundan elde edilir. Şüpheli genetik anormalliklerin ve hastalığa yatkınlığın, semptomların belirmesinden önce genetik testlerle doğrulanabilmesi veya reddedilebilmesi amaçlanmaktadır ${ }^{22}$. Bununla birlikte genetik test, bir bireyin belirli bir hastalığı geliştirmeye duyarlı olabileceğini gösterebilir; ancak, hastalığın ilgili kişide ortaya çıkıp çıkmayacağı veya ne zaman ortaya çıkabileceği veya hastalığın ne kadar şiddetli olabileceği konusunda bilgi vere$\mathrm{mez}^{23}$.

Çeşitli senaryolarda kullanılan bir dizi farklı genetik test bulunmaktadır ${ }^{24}$. Tanı amaçlı testler, prediktif testler ${ }^{25}$, taşıyıcılık testleri, embriyo tarama testleri, yeni doğan tarama testleri genetik testlere örnek olarak verilebilir $^{26}$. Isşyerinde kullanılabilecek genetik testler de genetik bir hastalığın olup olmadığına yönelik testler, ciddi hastalıklar için risk taşınıp taşınmadığına yönelik testler, işyeri ortamına bağlı hastalık riski olup olmadığının

Paor/Lowndes, s. 18; Ayrica bkz. Gürsel, s. 336.

Paor/Lowndes, s. 18.

Paor/Lowndes, s. 18.

ILO - Uluslararası Çalışma Ofisi Raporu - Equality at work: Tackling The Challenges, Global Report Under the Follow-Up To The ILO Declaration On Fundamental Principles And Rights At Work, International Labour Conference 96th Session 2007 Report I (B), https:/www.ilo.org/wcmsp5/groups/public/---dgreports/ dcomm/webdev/ documents/publication/wcms_082607.pdf, (09.05.2020), s. 48, p. 176; Aynı yönde Kim, s. 1504; Öte yandan belirli bir genetik özellik ile bir hastalık ilişkili olduğunda genetik testin öngörücü gücü testin analitik ve klinik geçerliliği gibi birçok faktöre bağlıdır, Kim, s. 1505-1506.

Paor/Lowndes, s. 18.

Prediktif test hakkında bkz. dn. 89; Yapılan çalışmalar sonucunda prediktif genetik teste tabi tutulanların, sonuçları öğrendikten sonra uzun süreli depresyon, benlik saygısı kaybı ve aile üyelerinden yabancılaşma gibi mağduriyetler yaşayabildikleri ortaya çıkmıştır. $\mathrm{Bu}$ nedenle genetik test yapılacak kişilere genetik testin riskleri ve yararları, bulguların sonuçları ve olumlu bir sonuç alındığında mevcut seçenekler konularında tam olarak bilgi verilmeden genetik test yapılmamalıdır, Kim, s. 1538.

Şen, s. 130. 
tespitine yönelik testler ve işyerinde kimyasal ve radyasyona zararlı seviyelerde maruz kalınıp kalınmadığına yönelik testler olarak sıralanabilir ${ }^{27}$.

Genetik bilgi kavramının açıklığa kavuşturulması açısından, bir bireyin genetik bilgilerinin genetik testler kullanılmadan da ortaya çıkarılabileceğini vurgulamak önemlidir. Genetik bilgiler, ilgilinin tıbbi geçmişlerinden elde edilen veriler ve aile tıbbi geçmişinin ayrıntıları aracıllğıyla keşfedilebilir. Aile tıbbi geçmişi geleneksel olarak güvenilir bir genetik bilgi kaynağı olmuştur ve kişilerin kan hısımlarının tıbbi geçmişinin analizinden önemli miktarda bilgi toplanabilmektedir. Bu nedenle, genetik bilgi kavramı ve bu tür bilgilerin kullanımı tartışılırken, hem genetik testlerin sonuçlarına hem de aile tıbbi geçmişinden elde edilen bilgilere başvurmak gerekir ${ }^{28}$. Daha açık deyişle genetik bilgilere DNA tabanlı testten, aile öyküsünden, hastane kliniğindeki veya internetteki teşhis hizmetlerinden elde edilen genetik test sonuçlarından ulaşılabiliir ${ }^{29}$.

Genetik bilgi ile bağlantılı olan diğer kavramlar, "genetik tarama" ve "genetik izleme" kavramlarıdır. Esasen genetik test ile genetik tarama aynı anlama gelmektedir. ILO'nun (International Labour Organization - Uluslar-

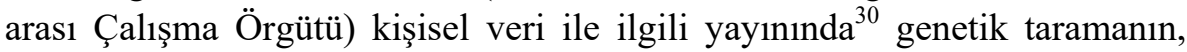
bireyin kalıtsal özelliklerine veya bozukluklarına odaklanan tek seferlik bir test olduğu; genetik izlemenin ise kişilerin genetik materyallerinde çevresel kaynaklı değişiklikler için periyodik olarak incelenmesini ifade ettiği belirtilmektedir ${ }^{31}$. Genetik izleme GINA'da da tanımlanmaktadır. Buna göre genetik izleme, çalışanların genetik materyallerinde, işyerindeki toksik maddelere maruz kalma nedeniyle, işyerindeki olumsuz çevresel maruziyetlerin etkilerini belirlemek, değerlendirmek ve bunlara müdahale etmek için kromozomal hasar veya mutasyonların artmış oluşumunun kanıtı gibi edinilmiş değişiklikleri değerlendirmek için gerçekleştirilen periyodik muayene anlamina gelir (m. 201/5).

Şen, s. 130-131.

Paor/Lowndes, s. 21; Aynı yönde Hellman, Deborah: "What Makes Genetic Discrimination Exceptional", American Journal of Law \& Medicine, Cilt 29, Say1 1, 2003, s. 80; Carr, Susannah: "Invisible Actors: Genetic Testing and Genetic Discrimination in the Workplace", University of Arkansas at Little Rock Law Review, Cilt 30, Say1 1, 2007, s. 10.

Paor/Lowndes, s. 21. https://www.ilo.org/public/libdoc/ilo/1997/97B09_118_engl.pdf, (01.05.2020). 


\section{B. Genetik Bilginin Özellikleri}

95/46/EC say1l1 Kişisel Verilerin İşlenmesi ve Bu Tür Verilerin Serbest Dolaşımına Dair Bireylerin Korunması Direktifinin ${ }^{32} 29$. maddesi uyarınca kurulan ve veri koruma ve gizlilik konusunda bağımsız bir danışma organı olan Çalışma Grubu, 2004 yılında Genetik Veri Hakkında Çalışma Belgesi yayımlamıştır $^{33}$ ve bu Belgede genetik bilginin özellikleri sıralanmaktadır. Buna göre genetik bilgi benzersizdir ${ }^{34}$ ve bir kişiyi diğer bireylerden ayırmakla birlikte aynı zamanda, sonraki ve önceki nesiller de dâhil olmak üzere, o bireyin kan hısımları hakkında bilgi ortaya çıkarabilir. Ayrıca genetik bilgi, etnik topluluklar gibi bir grup insanın ebeveyn ve aile bağları hakkında fikir verebilir ${ }^{35}$.

Genetik bilgi genellikle sahibi tarafından bilinmemektedir ve genetik bilgi değiştirilemez olduğu için sahibinin bireysel iradesine bağlı değildir.

Genetik bilgi kolayca elde edilebilir veya ham maddeden çıkarılabilir ve fakat bu bilgi, zaman zaman şüpheli kalitede olabilir.

Genetik bilginin özellikleri ile ilgili olarak doktrinde, genetik bilginin gelecekte daha fazla bilgi ortaya çıkarabileceği ve giderek artan sayıda kurum tarafından çeşitli amaçlar için kullanılabileceği sonucuna varılmaktadır ${ }^{36}$. Genetik teknolojileri ilerledikçe genetik testler tıbbi bakımın rutin

32 Direktif'in İngilizce metni için bkz. https://eur-lex.europa.eu/legal-content/en/TXT/? uri=CELEX\%3A31995L0046, (17.06.2020); Direktif'in Türkçe metni için bkz. https://kisiselveri.com/9546ec-turkce, (17.06.2020).

33 Çalışma Belgesi için bkz. https://ec.europa.eu/justice/article-29/documentation/opinion recommendation/files/2004/wp91_en.pdf, (04.03.2020).

34 Genetik bilgiyi ayırt edici ve özellikle hassas olarak tanımlayan ve fakat genetik bilginin özel olmadığı sonucuna varan görüş hakkında bkz. Spaak, Torben: "Genetic Discrimination”, Minn. J.L. Sci. \& Tech., Cilt 7, 2005-2006, s. 641-642; Paor/Ferri, s. 25.

35 Genetik bilgilerin kişinin kan hısımları hakkında bilgi ortaya çıkarması ile ilgili olarak İzlanda Yüksek Mahkemesi kararından bahsedilebilir. İzlanda'da bir kişi, babasının tıbbi kayıtlarının Sağlık Sektörü Veritabanına (Health Sector Database) aktarılıp aktarılmadığına ilişkin bilgi sahibi olmak istemiştir. Genetik bilgilerin kayıtlardan toplanabilmesi ve bu genetik bilgilerin kişiyle ilişkilendirilmiş olabilmesi hususu, söz konusu talebin gerekçesi olarak belirtilmiştir. Konu ile ilgili olarak İzlanda Yüksek Mahkemesi, temyiz eden davacının kişisel mahremiyeti nedeniyle babası hakkındaki bu tür bilgilerin veri tabanına aktarılmasını önleme hakkı bulunduğu gerekçesiyle davayı kabul etmiştir, Ragnhildur Guomundsd6ttir v The State of Iceland (No. 151/2003), Taylor, Mark J.:'Data Protection, Shared (Genetic) Data and Genetic Discrimination", Medical Law International, Cilt 8, Say1 1, 2006, s. 59.

36 Taylor, s. 57; Genetik bilginin özellikleri hakkında bkz. Küzeci, s. 98 vd; Paor/Ferri, s. $25 \mathrm{vd}$; Spaak, s. $641 \mathrm{vd}$. 
parçası haline gelecektir ${ }^{37}$. Aynı zamanda hastalık süreçlerinin daha iyi anlaşılması, bulaşıcı hastalıklarda genetik etkilerin rolünü ortaya çıkarabilir. Örneğin araştırmacılar genetik varyasyonların, hastalığın seyrini etkileyebilecek HIV enfeksiyonuna verilen bireysel tepkileri etkilediğine inanmaktadırlar ${ }^{38}$. Her türlü hastalı̆̆ın giderek genetik ve çevresel faktörlerden etkilendiği anlaşıldığ 1 ölçüde, genetik bilgiler bireysel tıbbi kayıtlarda yer alacak ve sağlık bilgilerinin bir parçası haline gelecektir ${ }^{39}$.

Genetik bilginin konumuz bakımından en önemli özelliği kişisel veri olmasıdır. Kişisel veri, belirli ya da belirlenebilir nitelikteki kişiye ilişkin her türlü bilgidir ${ }^{40}$. Avrupa Birliği Genel Veri Koruma Tüzüğü'nde de ${ }^{41}$ kişisel veri kavramı belirtilen şekilde tanımlanmaktadır. İsim, adres, kimlik numarası, konum bilgisi, çevrimiçi bir tanımlayıcı ve kişinin fiziksel, fizyolojik, genetik, zihinsel, ekonomik, kültürel veya sosyal kimliğine özgü bir veya daha fazla faktör, Tüzüğün kişisel veri tanımında örnek olarak ifade edilmektedir. Aynı şekilde 6698 sayılı Kişisel Verilerin Korunması Kanunu'nda $^{42}$ da kişisel veri aynı şekilde tanımlanmış olmakla birlikte Kanun kişisel verileri, "özel nitelikli kişisel veri” ve "özel nitelikli olmayan kişisel veri" olarak ikiye ayırmıştır. 6698 sayılı Kanuna göre kişilerin ırkı, etnik kökeni, siyasi düşüncesi, felsefi inanc1, dini, mezhebi veya diğer inançları, kılık ve kıyafeti, dernek, vakıf ya da sendika üyeliği, sağlı̆̆ı, cinsel hayatı, ceza mahkûmiyeti ve güvenlik tedbirleriyle ilgili verileri ile biyometrik ve genetik verileri özel nitelikli kişisel veridir (m. 6/1).

Belirtilen yasal düzenlemeler incelendiğinde, genetik bilginin kişisel veri olduğu hususunun vurgulandığ1 görülmekte hatta 6698 sayılı Kanun sistematiğinde, genetik bilginin özel nitelikli kişisel veri olarak nitelendirildiği anlaşılmaktadır.

\footnotetext{
$37 \quad$ Kim, s. 1545.

38 Kim, s. 1545

39 Kim, s. 1545

40 Küzeci, Elif: Kişisel Verilerin Korunması, Yenilenmiş ve Gözden Geçirilmiş 3. Bask1, Turhan Kitabevi, Ankara, 2019, s. 9; Manav, A. Eda: "İş İlişkisinde İşçinin Kişisel Verilerinin Korunması", Gazi Üniversitesi Hukuk Fakültesi Dergisi, Cilt XIX, Sayı 2, 2015, s. 97.

41 Avrupa Birliği Genel Veri Koruma Tüzüğü’nün İngilizce metni için bkz. https://gdprinfo.eu/, (29.04.2020); Tüzük hakkında bkz. Akıncı, Ayşe Nur: Avrupa Birliği Genel Veri Koruma Tüzügü̈nün Getirdiği Yenilikler ve Türk Hukuku Bakımından Değerlendirilmesi - Çalışma Raporu - 6, T.C. Kalkınma Bakanlığı Yayın No: 2968, Haziran 2017, http://www.bilgitoplumu.gov.tr/wp-content/uploads/2017/07/AB_Veri_Koruma_ Tuzugu.pdf, (10.06.2020), s. $10 \mathrm{vd.}$ 


\section{GENETIK AYRIMCILIK}

\section{A. Genel Olarak}

Genetik ayrımcılık, kısaca genetik özellikleri nedeniyle kişiye haksız bir şekilde farklı davranılması olarak tanımlanabilir ${ }^{43}$. Elde edilen genetik bilginin kötüye kullanılarak kişilere genetik ayrımcılık yapılabilme ihtimali bulunmakta olup toplumlarda bu konu ile ilgili hassasiyetin arttığı gözlemlenmektedir ${ }^{44}$.

Çoğu zaman, tarihsel açıdan bakıldığında fazlasıyla ayrımcılığa maruz kalan bazı 1rksal ve etnik azınlık grupların, genetik hastalıklar ile ilgili karakteristik özellikler göstermeleri durumu genetik ayrımcılık potansiyelini daha da artmaktadır ${ }^{45}$. GINA'nın giriş bölümünde ifade edildiği üzere birçok genetik durum ve bozukluk, belirli irk ve etnik gruplar ile hatta cinsiyetle ilişkilidir. Bazı genetik özellikler belirli gruplarda çok fazla yaygın olduğu için bu grupların üyeleri, genetik bilginin bir sonucu olarak damgalanabilir veya ayrımcılığa uğrayabilir. Bu ayrımcılık biçimi 1970'li yıllarda Amerika Birleşik Devletleri'nde ortaya çıkmıştır. O yıllarda, bir orak hücre popülasyonu tarama programı, Afrikalı-Amerikalıları gen taşıyıcısı olarak tanımlamış ve neticesinde Afrikal1-Amerikalıların birçoğu boşu boşuna işsiz kalmıştır ${ }^{46}$. Bir başka örnek Aşkenazi Yahudi topluluğunun, meme kanserine neden olan geni taşınmaları nedeniyle ayrımcılığa maruz kalmalarıdır ${ }^{47}$.

$\mathrm{Bu}$ noktada genetik ayrımcılığın, kökleri oldukça eskiye dayanan ırkcinsiyet vb. kökenli ayrımcı uygulamaları kapsamadığını vurgulamak gerekmektedir $^{48}$. Belirtilen ayrımcılık uygulamalarının nedenleri genetik biliminin sunduğu bir veriye dayanmamakta olup genetik ayrımcılık, "bireylerin

43 Paor/Ferri, s. 27; Smith ve Burns'e göre genetik ayrımcılık, sadece bireyin genetik yapısındaki 'normal' genomdan gerçek veya algılanan farklılıklar nedeniyle bir bireye veya o bireyin ailesinin üyelerine karşı ayrımcılıktır, Smith/Burns, s. 26; Genetik ayrımcılık hem fiziksel hem psikolojik bileşenleri kapsamaktadır, Krumm, Jennifer: "Genetic Discrimination: Why Congress Must Ban Genetic Testing in the Workplace", Journal of Legal Medicine, Cilt 23, Say1 4, 2002, s. 491.

Paor/Lowndes, s. 21, 69; Ayn1 yönde Krumm, s. 496.

Gardner-Hopkins, s. 439; Hellman, s. 88-89.

Gardner-Hopkins, s. 441; Kim, s. 1523; Krumm, s. 496; 1970’lerde söz konusu gen taşıyıcılarının belirli kimyasallara maruz kaldıklarında kan oksijen seviyelerinin düşebileceği düşünülüyordu. Günümüzde heterozigot taşıyıcıların yüksek irtifalarda bilincini kaybetme riski olduğu için hem İngiliz hem de Amerikan ordusunda hava mürettebatı eğitimi için başvuranlar bu gen için taranmaktadır, Gardner-Hopkins, s. 441. 
ya da yakınlarının mevcut ya da zannedilen genetik karakteristiğine dayalı olarak ayrık muameleye tabi tutulması" şeklinde tanımlanmaktadır ${ }^{49}$.

Öte yandan herkes, beş ila on arasında ölümcül resesif gene ve gelecekteki bir zamanda belirli hastalıkları geliştirmeye yatkın belirsiz sayıda gene sahip bulunduğundan, herkesin genetik ayrımcılığa maruz kalma riski bulunmaktadır ${ }^{50}$.

Genetik testlerin hem kişinin hem de toplumun sağllğı hakkında önemli kararlar almak için gerekli bilgileri vermesi bakımından ne kadar önemli olduğunu göz ardı etmemekle birlikte çalışmamızda artan genetik test yaygınlığının zaman içerisinde genetik zorlamaya dönüşmesi ihtimali dikkate alınmaktadır ${ }^{51}$.

Genetik ayrımcılık bireyin mevcut yeteneklerine değil, genetik koşulların veya yatkınlıkların gelecekteki tezahürlerine dayanmaktadır ${ }^{52}$. Doktrinde Asemptomatik veya presemptomatik olmasına rağmen genetik duyarlılı̆̆a sahip, gizli bir genetik hastalığı olan veya gelecekteki hastalığa genetik yatkınlığı olan bireyler; çekinik zararlı bir genin taşıyıcıları ${ }^{53}$; genetik koşullara sahip olan veya olduğu varsayılan bireylerin akrabalar ${ }^{54}$ özellikle genetik ayrımcılığa maruz kalma riski olan bireyler olarak sıralanmaktadır ${ }^{55}$.

Genetik ayrımcılık yasağının düzenlenmesinin, sadece adaletsizliğe karşı korunmak için değil aynı zamanda genetik bilgilerin aleyhimize kullanılması korkusu olmadan genetik test içeren biyomedikal gelişmelerden yararlanabilmek bakımından da önem arz ettiğini ifade etmekte fayda görmekteyiz $^{56}$. Amerika Birleşik Devletleri’nde bulunan Sağlık, Eğitim, Çalışma ve

49 Küzeci, s. 97; Aynı yönde Gardner-Hopkins, s. 438; Genetik ayrımcılık ile ırk ve cinsiyet temelli ayrımcılığın farkları hakkında bkz. Kim, s. 1500 vd.

50 Gardner-Hopkins, s. 439.

51 Ajunwa, s. 82; Genetik testlerin faydaları hakkında bkz. Paor/Lowndes, s. 21 vd.

52 Gardner-Hopkins, s. 438.

53 Bu tür bir ayrımcılık, bir taşıyıcı heterozigotun bir bozukluğa sahip olduğu veya bozukluk geliştireceği konusunda yanlış varsayıma veya çocuklarının geliştirme olasılığına dayanmaktadır, Gardner-Hopkins, s. 439.

$54 \mathrm{Bu}$ durum özellikle işverenin, işçi ve ailesi için bir çeşit sağlık sigortası sağladığı durumlarda meydana gelir, Gardner-Hopkins, s. 439.

55 Gardner-Hopkins, s. 438-439; Smith/Burns, s. 26.

56 Olick, Robert S.: "Genetic Discrimination in the Workplace After GINA", Genetic Discrimination Transatlantic Perspectives On The Case For a European-Level Legal Response, (Ed. Gerard Quinn, Aisling de Paor and Peter Blanck), Routledge, New York, 2015, s. 128. 
Emeklilik Senato Komitesi'nin ${ }^{57}$ (Senate Committee on Health, Education, Labor, and Pensions - HELP olarak kısaltılmaktadır) 2007 yılında yayımlanan genetik ayrımcılık konusu ile ilgili raporunda, genetik bilgilerin kötüye kullanılma korkusunun birçok insanın tıbbi bakımlarını geliştirecek genetik testlerden vazgeçmesine neden olacağ 1 sonucuna varılmaktadır ${ }^{58}$. Komite bu sonuca varırken, genetik testlere katılım isteksizliğini gösteren çeşitli çalışmalara dikkat çekmiştir. Komite özellikle, katılımcıların yüzde altmış üçünün sağlık sigortacılarının veya işverenlerinin sonuçlara erişebilmesi durumunda genetik test yapmayacaklarını söyledikleri bir telefon anketine atıfta bulunmuştur $^{59}$. Başka bir araştırmada hastaların yüzde altmış sekizi, ayrımc1lık korkusu nedeniyle klinik onkolojideki genetik testler için faturalandırma talep etmeyeceklerini bildirmişlerdir. Yine katılımcıların yüzde yirmi altıs1, sadece takma ad kullanabildikleri takdirde testlere gireceklerini belirtmişlerdir $^{60}$. Diğer bir çalışmada da kalıtsal kolon kanseri için risk altında olanların sadece yüzde kırk üçü genetik test programlarına katılmayı kabul etmiş ve katılmayı reddedenlerin yüzde otuz dokuzu sağlık sigortası kapsamı üzerindeki etkisinden dolayı yaşadıkları korkunun programa katılmamanın birincil nedeni olarak ifade edilmiştir ${ }^{61}$.

57 Yirmi iki senatörden oluşan Sağlık, Eğitim, Çalışma ve Emeklilik Senato Komitesi ABD'nin sağlık, eğitim, istihdam ve emeklilik politikaları konusunda geniş yargı yetkisine sahip üç alt komiteden oluşmaktadır. Komite ayrıca sağlık, eğitim ve öğretim ve kamu refahıyla ilgili konuları kapsamlı bir şekilde inceler, gözden geçirir ve belirli aralıklarla rapor hazırlar. Komite hakkında bkz. https://www.help.senate.gov/about, (26.04.2020).

58 Nemeth/Bonnette, s. 43.

59 Nemeth/Bonnette, s. 44; Aynı şekilde 1997 yılında 1000 kişinin katılımıyla gerçekleştirilen bir ankette, işverenlerin ve sağlık sigortacılarının sonuçları görebilmesi halinde katılımcıların yaklaşı üçte ikisi genetik test yaptırmayacaklarını beyan etmişlerdir. Yine katılımcıların yüzde 85 'i, işverenlerin bir bireyin genetik koşulları ve yatkınlıkları hakkında bilgi edinmesinin yasaklanması gerektiğini ifade etmişlerdir, Miller, Paul Steven: "Genetic Discrimination in the Workplace", Journal of Law, Medicine and Ethics, Cilt 26, Say1 3, 1998, s. 189.

60 Nemeth/Bonnette, s. 44.

61 Nemeth/Bonnette, s. 44; Georgetown Üniversitesi'ndeki araştırmacılar tarafından genetik destek gruplarına bağlı genetik bozukluğu olan bir veya daha fazla aile üyesi olan 332 kişiye yapılan anket sonucunda, katılımcıların yüzde 87'lik kısmı, genetik teste katıldıkları ve ciddi komplikasyonları olan genetik bir hastalık için yüksek risk altında bulundukları hakkında işverenlerinin bilgi sahibi olmasını istemeyeceklerini söylemişlerdir. Katılımcıların yüzde 17'si, işlerini ya da sigorta kapsamını kaybetme korkusuyla işverenlerine, genetik bilgileri açıklamadıklarını belirtmişlerdir, Miller, s. 189-190; Katılımcıların yüzde 13'ü genetik durum nedeniyle kendilerinin veya bir aile üyesinin işten çıkarıldığını bildirmiştir, Miller, s. 191. 


\section{B. İș Hukukunda Genetik Ayrımcılık}

Genetik bilgi özellikle İş Hukuku ve Sigorta Hukuku alanında risk teşkil etmektedir. $\mathrm{Bu}$ iki alanda genetik bilginin kullanımı genetik ayrımcılığa sebep olabilmektedir ${ }^{62}$. Bu iki alanda genetik ayrımcılığa maruz kalma riski GINA'nın giriş bölümünde de ifade edilmektedir. Örneğin işe alımdan önce ya da iş ilişkisi süresince gerçekleştirilen tıbbi muayene çerçevesinde ya da sigorta sözleşmesi oluşturulurken genetik bilginin kullanımı ayrımcı uygulamalara temel oluşturabilmektedir ${ }^{63}$. İşverenler ve sigorta şirketleri kararlarını genetik bilgiye dayandırmayı ve bazı durumlarda işçilerin veya poliçe sahiplerinin genetik teste tabi tutulmasını isteyebilmektedirler ${ }^{64}$. Çalışmamızda genetik ayrımcılığın Sigorta Hukuku üzerindeki değil İş Hukuku üzerindeki etkisine yer verilecektir.

Amerika Birleşik Devletleri'nde bulunan Genetik Adalet Koalisyonu ${ }^{65}$ işverenlerin genetik testi, bir iş̧̧inin gelecekteki sağlığı ve dolayısıyla gelecekteki devamsızlık düzeyi veya düşük çalışma oranı ile ilgili bir öngörü

62 Küzeci, s. 111; Aynı yönde Paor/Ferri, s. 27; Smith/Burns, s. 26; Rojas, s. 568; 1997 yılında, Stanford Üniversitesi'nde klinik tıp profesörü olan Paul R. Billings, genetik bilgilerin kötüye kullanılması potansiyeli hakkında erken bir uyarıda bulundu. Billings, "genetik ayrımcllık zaten sigorta ve istihdam alanlarında meydana gelmekte, ek olarak evlat edinme ve askerlik alanlarına da ulaştı̆̆ını" ifade etti, 8M, s. 82; Genetik bilgiye erişimin genetik ayrımcılığa yol açıp açmadığını belirlemek amacıyla 1992 yılında yapılan bir araştırmada klinik genetik, genetik danışmanlık, engellilik, pediatri ve sosyal hizmetler alanında çalışan 1.119 uzmana genetik ayrımcılık vakaları sorulmuştur. Alınan 42 yanıttan 13'ü (\%31), genetik ayrımcılık konusundaki kriterleri karşılamadığından veya doğru bir değerlendirme için yeterli bilgi sağlamadığından çalışmadan çıkarılmıştır. ABD ve Kanada'nın tüm bölgelerinden gelmiş olan diğer 29 yanıt değerlendirildiğinde, 41 ayrı ayrımcılık olayının bildirildiği anlaşılmış ve 41 olayın ikisi hariç diğer hepsinin istihdam ve sigortacılık alanına ilişkin olduğu sonucuna varılmıştır, Billings, Paul R. ve diğerleri: "Discrimination as a Consequence of Genetic Testing", Am. J. Hum. Genet., Cilt 50, 1992, s. 477 vd; Sigorta Hukukunda genetik bilgiyi esas alarak sınıflandırma yapmak suretiyle daha yüksek prim uygulamasına gidilip gidilemeyeceği sorusuna olumlu ve olumsuz cevap veren baskın iki görüş bulunmaktadır. Detaylı bilgi için bkz. Küçük, Damla: "Sigortacılıkta Haksız Ayırımcı Uygulamalar Bağlamında "Verimli Sınıflandırma" ve "Adil Sınıflandırma" Yaklaşımlara Kısa Bir Bakış", Uluslararası Akademik Araştırmalar Kongresi, 16-17-18 Eylül 2019 Bolu, Sempozyum Özet Kitapçı̆̆ı, Makale ID: 92, https://kongre.akademikiletisim.com/files/icar2019/icar_ ozet_kitapcigi.pdf, s. $331 \mathrm{vd}$.

Küzeci, s. 111

Spaak, s. 640.

65 Genetik Adalet Koalisyonu, GINA'nın düzenleme süreci hakkında bilgilendirmede bulunur, paydaşların ihtiyaçlarını karşılar. Ek olarak çeşitli eğitim materyalleri, kaynakları ile araçları oluşturur ve yayar. Detaylı bilgi için bkz. http://www.geneticfairness.org/ index.html, (10.04.2020). 
aracı olarak kabul ettiklerini bildirmiştir ${ }^{66}$. Koalisyon, gelecekteki sağl1k durumu temelinde iş başvurusunda bulunanların dışlandığ çeşitli vakalar bildirmiştir $^{67}$. Aynı şekilde ILO'nun 2007 tarihli Raporunda da işverenlerin, genetik durumu gelecekte belirli bir hastalığın geliştirilmesine yatkınlık gösteren işçileri dışlama veya işten çıkarma ile ilgilenebileceğinden söz edilmektedir ${ }^{68}$.

Esasen çalışma hayatında işçiler, eğitim düzeyleri, önceki iş deneyimleri, kıyafet standartları gibi özelliklere göre sıklıkla ayrımcılığa maruz kalmaktadır $^{69}$. Bazı işverenler genetik bilgilerin, karar verme süreçlerine dâhil edilebilmesi gerekliliğini ileri sürmektedirler. Bu görüşteki işverenler genetik bilgi kullanımının, maliyet etkin planlama stratejilerini destekleyebileceğini, çalışan verimliliğini en üst düzeye çıkarabileceğini, çalışanların tazminat talebi maliyetlerini ve sağlık sigortası primlerini azaltabileceğini ve haksız fiil hukuku uyarınca gelecekteki sorumluluk risklerini en aza indirebileceğini iddia etmektedirler ${ }^{70}$. Söz konusu talebin kabul edilmesi, bir başka deyişle genetik ayrımcılıkla ilgili yasal kısıtlama bulunmaması durumunda birçok işveren kaçınılmaz olarak, zayıf genetik kayıtlara sahip olduğunu düşündükleri işçileri işe almama veya işten çıkarma yönünde davranış sergileyeceklerdir ${ }^{71}$.

Doktrinde işverenlerin, genel olarak potansiyel veya mevcut bir çalışanın genetik bilgisiyle ilgilenme sebebi olarak dört adet gerekçe sıralanmaktadır. Buna göre işverenler, bir işçinin çalışma ortamından dolayı belirli hastalıkları geliştirmeye yatkınlığını bilmek, iş arkadaşlarının güvenliği için risk oluşturabilecek işçileri belirlemek, spesifik hastalık geliştirme riski daha yüksek olan işçileri tespit etmek ve işle ilgili tıbbi nitelikleri doğru olan kişileri işe almak istemektedirler ${ }^{72}$. Örneğin bir kişinin petrokimyasal ürünlerde bulunan benzenden etkilenme şiddeti ile NQO1 gen değişiklikleri arasında ilişki bulunmakta olup; bu tür bir gen testi ile etkilenme riski olan işçilerin, söz konusu maddelerden korunması sağlanacaktır ${ }^{73}$. Yine işyerinde kimyasal maddeye maruz kalabilen işçilerin DNA'larında bir yapısal hasar olup oluşmadığını belirlemeye yönelik genetik testler örnek olarak verile-

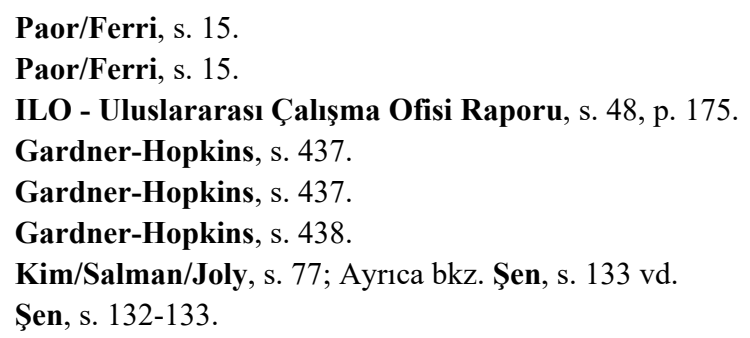


bilir. Bu testler ile oluşabilecek bir hastalık riski için gösterge elde edilebilecektir ${ }^{74}$. Ancak bu gerekçeler, İş Hukukunda işçinin korunması ilkesinden uzaklaşarak zaman içerisinde genetik ayrımcılığın yaygınlaşması riskini barındırmaktadır. Çünkü genetik testler hangi işçilerin sağlıklı, üretken ve sağlık sigortası bakımından daha az maliyetli olacağını tahmin etmede kullanılabildiği için işverenlere karını artırma imkânını sunmaktadır ${ }^{75}$. Ancak işverenlerin bireysel olarak elde ettikleri ekonomik fayda genel ekonomi ve toplum üretkenliği açısından geçerli olmayacağı gibi genetik ayrımcılığın artmasına da neden olacaktır ${ }^{76}$.

Yakın zamanda yapılan bir Kanada araştırması, Huntington hastalığı riski taşıyan test edilmiş veya test edilmemiş asemptomatik birçok kişinin iş ararken genetik ayrımcılık yaşadığını bildirmiştir ${ }^{77}$. Genetik bilgi kullanımının İş Hukuku bakımından tehlikelerini ortaya koyan bir diğer örnek, Norman-Bloodsaw ve Lawrence Berkeley Laboratuvarı davasıdır ${ }^{78}$. Bu davada işçiler tarafindan kolesterol testi için kan ve idrar örnekleri verildiği; ancak Laboratuvar'ın işçilerin bilgisi ve rızası olmadan sifiliz, hamilelik ve orak hücre özelliği için de test yaptığı iddia edildi. Dokuzuncu Bölge Adliye Mahkemesi, gebelik testi ile cinsiyet ayrımcılığının, orak hücre testi ile cinsiyet ve 1rk ayrımcıllğı yapıldığg yönünde karar vermiştir ${ }^{79}$.

Genetik ayrımcıllı̆a karşı daha fazla yasal koruma sağlanması gerekliliğini ortaya koyan durumlara örnek olarak 2014 yılında AOL CEO’su Tim

\footnotetext{
Şen, s. 133.

Krumm, s. 497.

76 Krumm, s. 498; Genetik testlerin topluma ekonomik olarak faydalı olacağını savunan görüş hakkında bkz. Krumm, s. 499.

Kim/Salman/Joly, s. 77.

135 F 3d 1260 (9 Cir 1998), Gardner-Hopkins, s. 441, dn. 42.

79 Gardner-Hopkins, s. 441; Ajunwa, s. 89-90; Nemeth/Bonnette, s. 44; Kim, s. 1513; Miller, s. 192; Carr, s. 6; Doktrinde Ajunwa'ya göre İş Hukukunda genetik ayrımcılığa bir diğer örnek, hasta değil iken yaptırdığı bir genetik test sonucunda meme kanseri ihtimalini artıran BRCA2 taşıyıcısı olduğu ortaya çıkması üzerine işten kovulan Pamela Fink'dir, Örnek hakkında bkz. Ajunwa, s. 77; Yine ABD'de Fabricut, Inc.'e iş başvurusu yapan kişiye, uyuşturucu testi yaptırması ve anket doldurması şartı sunuldu. Doldurulması gereken ankette, aile tıbbi öyküsünde kalp hastalığı, kanser, diyabet, artrit ve zihinsel bozukluklar gibi belirli hastalıkların olup olmadığına yönelik sorular bulunmaktaydı. Kişiye yaptırılan diğer tıbbi testlerde, karpal tünel sendromu ile ilgili bir şüphe ortaya çıkardı ve işe başvuran kişinin kişisel doktorunun, kişide karpal tünelinin olmadığını tespit etmesine rağmen şirket, kişiyi işe almaktan vazgeçti. Söz konusu kişinin Eşit İstihdam Fırsatı Komisyonuna (Equal Employment Opportunity CommissionEEOC) başvurusu üzerine şirket, 50.000 dolar para cezası ödemek için adımlar atmayı kabul etti, Olick, s. 134; Ajunwa, s. 92-93 Eşit İstihdam Fırsatı Komisyonu hakkında çalışmamızın devamında bilgi verilecek olup, bkz. IV.A.
} 
Armstrong'un, şirketinin emeklilik harcamalarını kısıtlamasının sebebini, sıkıntılı bebeğe (distressed babies) sahip iki çalışanına atfetmesi olayı verilebilir $^{80}$. Şöyle ki Tim Armstrong’un bebeklerin tedavisi için milyon dolarlar harcandığını ve şirketin sağlık maliyetlerinin artmasına neden olmasından bahsettiği cümlelerinin haber olması üzerine Armstrong'un, "s1kıntılı bebeklere sahip olma" riski daha yüksek olan işçilerini belirleyebilmesi ihtimali gündeme gelmiştir. Genel olarak işverenlerin, şirketlerinin sağlık bakım maliyetlerinin artma korkuları dikkate alındığında, "işverenlerin istihdam edecekleri bireyleri seçerken söz konusu bilgileri kullanmalarına izin verilmeli midir?" sorusu tartışma konusu olmuştur ${ }^{81}$. Yine 23 andMe şirketi ${ }^{82}$ ile Pfizer ve Genentech gibi şirketlerin, sağlık araştırmaları için büyük genetik veri tabanlarına erişimlerinin ticaretini içeren son anlaşma haberleri de genetik ayrımcılığa karşı daha fazla yasal koruma ihtiyacını çıkaran durumlar arasinda ifade edilmektedir ${ }^{83}$.

\section{GENETIK AYRIMCILIK YASAĞINA İLIŞKKIN ULUSLARARASI DÜZENLEMELER}

Üçüncü şahıslar tarafından genetik bilgi kullanımını sınırlamak veya genetik ayrımcılığ 1 doğrudan yasaklamak için uluslararası ve ulusal olarak çeşitli yaklaşımlar geliştirilmiştir ${ }^{84}$. Aynı şekilde işverenlerin genetik bilgi kullanımının yasal olarak düzenlenmesi gereği de uluslararası alanda vurgulanmıştır $^{85}$. Alanında bağlayıcılığı olan ilk uluslararası sözleşme 1997

$80 \quad$ Ajunwa, s. 76.

81 Ajunwa, s. 76; Haber metni için bkz. http://www.msnbc.com/msnbc/aol-backtracksafter-distressed-babies-flap, (10.03.2020); Tim Armstrong belirtilen beyanları nedeniyle özür dilemek zorunda kalmıştır, Ajunwa, s. 76.

82 23andMe şirketi, hizmet satın alan kişilerin tükürüğünden genetik verileri analiz edip, kişiye genetik analizinin raporunu sunmaktadır. Bkz. https://www.23andme.com/en-eu/ genetic-science/, (23.04.2020); 23andMe şirketi ve yaklaşık 22 genetik test şirketi hakkında yapılan bir araştırmada, tüketiciler ile şirketler arasındaki hiçbir anlaşmada genetik bilgilerin yanlışlıkla ifşa edilmesi durumu ile ilgili bir düzenlemenin olmadığı sonucuna varılmıştır. Konu ile ilgili genetik ayrımcılık tehlikesi hakkında bkz. Ajunwa, s. $103 \mathrm{vd}$.

Ajunwa, s. 76-77.

84 Kim/Salman/Joly, s. 72; Kim, Salman, Joly tarafından bu yaklaşımlar insan hakları temelli-yasaklayıcı temelli - sınırlayıcı temelli - moratoryum temelli ve statüko temelli olarak sınıflandırılmaktadır. Detaylı bilgi için bkz. Kim/Salman/Joly, s. 72 vd.

85 Gardner-Hopkins, s. 453; 2002 y1lında, İngiltere İnsan Genetiği Komisyonu (HGC), insanları genetik ayrımcılığa karşı koruyan özel mevzuata dikkat edilmesi gerektiğini önerdi. Komisyon 2011 yılında da genetik ayrımcılıkla ilgili mevzuat değişikliği ihtiyacının devam ettiğini belirtti. 2003 yılında Bilim ve Yeni Teknolojilerde Etik Grubu 
yılında Avrupa Konseyi tarafından onaylanan Biyoloji ve Tibbın Uygulanması Bakımından İnsan Hakları ve İnsan Haysiyetinin Korunması Sözleşmesi: İnsan Hakları ve Biyotıp Sözleşmesi'dir (Oviedo Sözleşmesi olarak da anılır $)^{86}$. Biyotıp Sözleşmesi ile ilgili ilk belirtilmesi gereken husus, bu Sözleşme ile Avrupa İnsan Hakları Sözleşmesi'nin 14. maddesinde sıralanan ayrımcılık temeli oluşturan konuların arasına genetik ayrımcılığın da eklenmesinin kabul edilmesidir ${ }^{87}$. Biyotıp Sözleşmesi'nin "Ayrım yapmama" başliklı 11. maddesine göre "Bir kimseye, genetik kalıtımı nedeniyle herhangi bir ayrımcılık uygulanması yasaktır". Yine Biyotıp Sözleşmesi'nin "Genetik teşhise yönelik testler ${ }^{88 "}$ başlıklı 12. maddesine göre "Genetik hastalıkları teşhise yönelik veya ya kişinin bir hastalığa neden olan bir geni taşıdığını belirlemeye ya da genetik bir yatkınlığı veya bir hastalığa eğilimi ortaya çıkarmaya yönelik testler, sadece sağlık amaçlarıyla veya sağlik amaçlı bilimsel araştırma için ve uygun genetik danışmada bulunmak şartıyla yapılabilir".

Avrupa Birliği Temel Haklar Şartı'nın 21. maddesinde sıralanan ayrımcılık yasağı kapsamına giren konular arasında genetik özellikler de yer $\operatorname{almaktadir}^{89}$.

UNESCO - Birleşmiş Milletler Eğitim, Bilim ve Kültür Örgütü tarafindan 1997 yılında, "İnsan Genomu ve İnsan Hakları Evrensel Bildirgesi" yayımlanmış $^{90}$ ve Bildirge'de açıkça genetik ayrımcılık yasaklanmıştır' ${ }^{91}$.

(EGE), Avrupa Birliği’ne genetik ayrımcılık konusunda acil eylem çağrısında bulundu, Paor/Ferri, s. 15-17.

Paor/Ferri, s. 15; Küzeci, s. 90-91; Biyotıp Sözleşmesi, TBMM tarafindan 5013 sayılı Kanun ile 03.12.2003 tarihinde kabul edilerek, 20.04.2004 tarihli ve 25439 sayll Resmi Gazete'de yayımlanarak yürürlüğe girmiş̧ir. Sözleşmenin Türkçe metni için bkz. https://www.tbmm.gov.tr/kanunlar/k5013.html, (12.04.2020); Sözleşmenin İngilizce metni için bkz. https://rm.coe.int/CoERMPublicCommonSearchServices/Display DCTMContent?documentId $=090000168007 \mathrm{cf} 98,(12.04 .2020)$.

Küzeci, s. 103.

Doktrinde Küzeci’ye göre Biyotıp Sözleşmesi'nin 12. maddesinin başlığının (Predictive genetic tests) "genetik öngörü testleri" olarak çevrilmesi durumunda hem sözcüksel hem amaçsal açıdan hükmün içeriği daha doğru şekilde karşılanmış olacaktır, Küzeci, s. 108, dn. 79.

Paor/Ferri, s. 17; Küzeci, s. 16-17; Doktrinde Paor, Ferri’ye göre Avrupa Birliği Temel Haklar Şartı'nın 21. maddesi, Üye Devletlerin genetik ayrımcılıkla mücadele yasalarını yürürlüğe koymaları için herhangi bir etki yaratmamaktadır, Paor/Ferri, s. 19; Ek olarak genetik ayrımcılık yasağı ile ilgili Avrupa Birliği nezdinde yasal düzenleme eksikliği ve gerekliliği hakkında bkz. Paor/Ferri, s. 18 vd. 
Bildirge'nin 6. maddesine göre hiç kimse insan haklarını, temel özgürlükleri ve insan onurunu zedeleyecek şekilde genetik özellikleri nedeniyle ayrımcılığa tabi tutulmamalıdır. Konu ile ilgili olarak UNESCO tarafından ayrıca 2003 y1lında İnsan Genetik Verileri Uluslararası Bildirgesi ve 2005 y1lında UNESCO Biyoetik ve İnsan Hakları Evrensel Bildirgesi ${ }^{92}$ yayımlanmıştır ${ }^{93}$.

Birleşmiş Milletler Ekonomik ve Sosyal Konseyi de 2004 y1lında "Genetik Gizlilik ve Ayrımcılık Yapmama" başlıklı bir karar çıkarmış ve Konsey bu kararı ile devletleri, ayrımcılığa yol açan genetik bilginin kötüye kullanılmasına karşı önlemler almaya çağırmışıı ${ }^{94}$.

Genetik ayrımcılık konusuna ILO'nun yaklaşımını inceleyecek olur isek öncelikle ILO tarafından yayımlanan Çalışanların Kişisel Verilerinin Korunmas1 isimli yayında, genetik taramanın yasaklanmas1 ya da ulusal mevzuatta açıkça izin verilen durumlarla sınırlanması gerekliliğine işaret edildiğini belirtmek gerekmektedir ${ }^{95}$. Söz konusu yayında ayrıca genetik taramanın, genetik kodlarından kaynaklanan tehlikeleri önlemenin işçilerin yararına olduğu gerekçesiyle giderek daha fazla savunulduğu ve fakat genetik taramanın aynı zamanda bir çalışanın geleceği için geniş kapsamlı etkileri olan bir dizi son derece kişisel veriyi ifşa edebilecek nitelikte olduğu ifade edilmektedir. Bu nedenle çalışanları bu tür muayenelere tabi tutmanın işverenin takdirine bırakılamayacağı ve zorlayıcı nedenler veya genetik teste uygulan bir alternatifin olmadığı istisnai durumlarla sınırlandırılması gerektiği belirtilmektedir ${ }^{96}$.

\section{GENETIK AYRIMCILIK YASAĞINA İLISŞKİN AMERIKAN HUKUKUNDAKI VE TÜRK HUKUKUNDAKİ DÜZENLE- MELER}

\section{A. Amerikan Hukuku}

Amerika Birleşik Devletleri genetik ayrımcılık konusunda en çok incelenen ülkeler arasında yer almaktadır. ABD'de genetik ayrımcılıkla ilgili örnek sayısının ve dolayısıyla mağduriyetin fazla olması ve daha sonra koruyucu mevzuatın yürürlüğe girmesi ile $\mathrm{ABD}$, genetik ayrımcılık bakımın-

Kim/Salman/Joly, s. 72; Gardner-Hopkins, s. 453.

Bildirge'nin İngilizce metni için bkz. http://portal.unesco.org/en/ev.php-URL_ID= 31058\&URL_DO=DO_TOPIC\&URL_SECTION=201.html, (16.04.2020).

Küzeci, s. 107, dn. 74.

Kim/Salman/Joly, s. 72.

Protection of Workers' Personal Data, s. 6; Ayrıca bkz. Küzeci, s. 112.

Protection of Workers' Personal Data, s. 34-35.
} 
dan dikkat çekici nitelik kazanmaktadır ${ }^{97}$. Bu nedenle çalışmamızda, İş Hukukunda genetik ayrımcılık konusu ile ilgili Amerikan Hukukunda federal düzenleme olan 2008 tarihli GINA'yı incelemekte fayda görmekteyiz. ABD'nin kendine özgü sağlık sigortası sistemi nedeniyle işverenler birincil sigorta sağlayıcısıdır ve bazı durumlarda doğrudan bakım maliyetini karş1lamaktadırlar $^{98}$. Bu nedenle işverenlerin gelecekteki sağlık maliyetlerinden tasarruf etmek için genetik riskler hakkında bilgi edinme konusunda potansiyelleri bulunmaktadır. Daha açık deyişle bir işveren, bir kişinin kanser veya başka bir kalıtsal hastalık geliştirebileceği bilgisini edinirse, işverenin kişiyi işe almaktan kaçınması yüksek bir ihtimaldir ${ }^{99}$.

GINA'dan önce ABD'de İş Hukuku ve Sigorta Hukuku konularında federe yasalar bulunmaktaydı ve fakat söz konusu yasaların dağınık nitelikte olması nedeniyle Amerikalılar, çoğu konu ile ilgili haklarında belirsizlik yaşamışıır ${ }^{100}$. Öte yandan ABD'deki karmaşık sağlık sigortası sistemi, hem federal hem de eyalet düzeylerindeki genetik ayrımcılığa karşı korumadaki boşluklar ve genetik ayrımcıllğı bir sivil haklar sorunu olarak görme hareketi konuyu ulusal düzeyde ele alacak kapsamlı bir yasa gereğini ortaya koymuștur ${ }^{101}$.

21 Mayıs 2008'de Başkan George W. Bush tarafından imzalanan GINA'nın yürürlük tarihi, 21 Kasım 2009 olarak belirlenmiştir ${ }^{102}$. GINA genetik bilgiye dayalı ayrımcılık yapılmasına karşı koruma sağlamayı amaçlamaktadır. Esasen GINA önleyici bir mevzuattır, gelecekte yaygınlaşmadan önce yeni bir ayrımcılık biçimini engellemeyi hedeflemektedir ${ }^{103}$.

97 ABD'nin genetik ayrımcılık bakımından dikkat çekici olması ile ilgili 1996 yılında ülke çapında yapılan bir ankette, katılımcıların \% 13'ünün kendilerinin veya ailelerinden birinin genetik bir durumun doğrudan bir sonucu olarak işini kaybettiklerini iddia etmeleri ve yine 2000 yılında Massachusetts'te yapılan bir araştırmada, genlerinde keşfedilen "kusurlar" nedeniyle iş için reddedilen 580'den fazla kişinin olması örnekleri verilebilir, Ajunwa, s. 87.

98 Prince/Waterstone, s. 124; Kim, s. 1540.

99 Prince/Waterstone, s. 124.

100 Prince/Waterstone, s. 117

101 Prince/Waterstone, s. 117-118.

102 Nemeth/Bonnette, s. 42.

103 Blanck, Peter/Paor, Aislıng De: "US Legislative and Policy Response: Some Historical Context to GINA", Genetic Discrimination Transatlantic Perspectives On The Case For a European-Level Legal Response, (Ed. Gerard Quinn, Aisling de Paor and Peter Blanck), Routledge, New York, 2015, s. 106-107. 
GINA $^{104}$ İş Hukuku ve Sigorta Hukuku olmak üzere iki bölümden oluşmaktadır ${ }^{105}$. Birinci bölüm sigortacılar ve sağlık planları için geçerlidir. $\mathrm{Bu}$ bölümde bir kayıt sahibinin, genetik bilgilerinin sonuçlarına dayanarak grup için primlerin artırılması veya kaydın reddedilmesi gibi genetik bilgiye dayalı grup sağlık sigortası primlerinin uygunluğunu veya maliyetini belirleme konusunda ayrımcılık yasaklanmaktadır. Benzer şekilde, sigorta şirketlerinin ne zaman genetik bilgi talep edebileceklerine veya toplayabileceklerine kisitlamalar getirilmektedir ${ }^{106}$.

İkinci bölümde ise çalışma konumuzu oluşturan İş Hukukunda genetik ayrımcılık düzenlenmektedir. İkinci bölüm on beş veya daha fazla işçisi olan özel sektördeki işyerleri için geçerlidir ${ }^{107}$. İkinci bölümün ilk maddesi olan 201. maddede tanımlara yer verilmektedir. Çalışmamızda daha önce ilgili tanımlara değinmiş olmakla birlikte bazı tanımlara burada özellikle değineceğiz. Buna göre GINA m. 201/7-B'ye göre "Genetik test" terimi, genotipleri, mutasyonları veya kromozomal değişiklikleri tespit eden insan DNA, RNA, kromozomlar, proteinler veya metabolitlerin analizi anlamına gelmektedir. Doktrinde Ajunwa'ya göre söz konusu tanım nedeniyle, DNA, RNA veya tam kan sayımı, kolesterol testleri ve karaciğer fonksiyon testleri gibi kromozomal değişiklikleri ölçmeyen testlerin sonuçları GINA kapsamında korunmamakta ve orak hücre anemisi gibi bazı genetik hastalıkların basit bir kan testi ile belirlenebilmesi nedeniyle GINA, genetik ayrımcılık için gri bir alan sunmaktadır ${ }^{108}$.

GINA m. 201-6'ya göre "Genetik hizmetler" terimi genetik test, genetik danışma (genetik bilgi edinme, yorumlama veya değerlendirme dâhil) ve genetik eğitim kavramlarından oluşmaktadır.

"Aile üyesi" kavramının m. 201/3-B'de, bir bireyin birinci derece, ikinci derece, üçüncü derece veya dördüncü derece akrabası olan herhangi

\footnotetext{
104 GINA hükümleri için ayrıca bkz. Şen, s. 139-140.

105 GINA'nın yalnızca iki alanla ilgili düzenleme içermesi nedeniyle ilgili eleştiri için bkz. Prince/Waterstone, s. 114, 126.

106 Prince/Waterstone, s. 107; GINA'nın belirtilen bölümü hakkında detaylı bilgi için bkz. Prince/Waterstone, s. $119 \mathrm{vd}$.

107 Tanımlarının yer aldığı GINA'nın 201. maddesinde “işveren” kavramı için 1964 tarihli İnsan Hakları Kanununa (Civil Rights Act of 1964) atıfta bulunulmaktadır. Belirtilen Kanunun ilgili kısmı incelendiğinde işveren ile on beş veya daha fazla sayıda işçi çalıştıran özel sektör işverenlerinin ifade edildiği anlaşılmaktadır.

Ajunwa, s. 94.
} 
bir diğer birey olarak tanımlandığını daha önce ifade etmiştik ${ }^{109}$. Ek olarak GINA'da, genetik bilgi ile ilgili olarak sadece aile üyesi bilgisine değil bir fetüs ve embriyo bilgisine de atıfta bulunulmaktadır ${ }^{110}$. GINA m. 208-b'de, bir bireyin veya bir bireyin aile bireyi ile ilgili genetik bilgilere yapılan atıfların, hamile kadın tarafından taşınan herhangi bir fetüsün genetik bilgilerini ve yardımcı üreme teknolojisi kullanan bir birey veya aile üyesi ile ilgili olarak, birey veya aile üyesi tarafindan yasal olarak tutulan herhangi bir embriyonun genetik bilgilerini içerdiği düzenlenmektedir.

"Genetik Bilgiye Dayalı Ayrımc1lık" başlıklı m. 202/a'ya göre,

(1) Genetik bilgi nedeniyle işçiyi işe almamak veya işten çıkarmak veya işçiye, ücret ve çalışma şartları bakımından ayrımcılık yapmak yasaktır.

(2) Genetik bilgi nedeniyle istihdam firsatlarından mahrum edecek veya işçinin durumunu olumsuz etkileyecek şekilde ayrımcılık yapmak yasaktır.

"Genetik Bilgilerin Edinilmesi” başlıklı m. 202/b’ye göre, bir işverenin, bir işçi veya işçinin bir aile üyesi ile ilgili genetik bilgi istemesi, talep etmesi veya satın alması yasaktır. Ancak düzenlemenin devamında istisnalar düzenlenmektedir. Buna göre bir işverenin yanlışlıkla işçinin veya işçinin aile üyesinin aile tıbbi geçmişini istemesi veya talep etmesi ${ }^{111}$; bir sağlık programının parçası olarak sunulan hizmetler de dâhil olmak üzere işveren tarafindan önerilen sağlı hizmetleri veya genetik hizmetler; işçinin önceden, bilerek, gönüllü olarak ve yazılı izin vermesi ${ }^{112}$; ilgili işçinin (veya aile üyesi genetik hizmet alıyorsa aile üyesinin) ve bu tür hizmetlerin sağlanmasında yer alan lisanslı sağlık uzmanının veya sertifikalı genetik danışmanın bu tür hizmetlerin sonuçları hakkında bilgi alması; işçilerin kimliğinin açıklanmadığı toplu halde genetik bilginin bulunması; bir işverenin mevzuattan kaynaklanan gerekliliklere uyması sebebiyle işçinin aile tıbbi geçmişini talep etmesi; bir işverenin aile tıbbi geçmişini içeren ticari ve kamuya açık belgeleri (gazeteler, dergiler, süreli yayınlar ve kitaplar dâhil ancak tıbbi veri

109 İnsanlar ailelerinin genetik bilgileri nedeniyle ayrımcıllğa maruz kalabilmektedir. Kardeşinin Gaucher hastalığ1 olduğu öğrenilen kişinin yahut ailesinde Huntington hastalı̆̆ 1 olduğu öğrenilen kişinin işten çıkarılması örnek olarak verilebilir, Krumm, s. 514.

110 Prince/Waterstone, s. 118; GINA m. 209-b'ye göre hamile bir kadının veya aile üyesinden birinin fetüsünün ve destekli üreme teknolojisini kullanan bir kişi veya aile üyesi tarafindan yasal olarak tutulan herhangi bir embriyonu.n genetik testleri de genetik bilgi kapsamındadır. Konu hakkında bkz. Ajunwa, s. 91

$111 \mathrm{Bu}$ istisna, bütün genetik bilgiler için değil sadece aile tıbbi geçmişi için geçerlidir, Nemeth/Bonnette, s. 43.

112 Genetik bilgi ile ilgili "aydınlatılmış onam” elde etmenin mümkün olmaması hakkında bkz. Krumm, s. 511 vd. 
tabanları veya mahkeme kayıtları dâhil değil) satın alması ${ }^{113}$ yasak kapsamında değildir ${ }^{114}$. Aynı şekilde genetik bilgilerin, işyerindeki toksik maddelerin biyolojik etkilerinin genetik olarak izlenmesi için kullanılması gerektiğinde işverenin, işçiye genetik izleme hakkında yazılı bildirimi üzerine işçinin önceden, bilerek, gönüllü olarak ve yazılı şekilde izin vermesi veya genetik izlemenin bir kanun tarafından zorunlu tutulması şartlarının gerçekleşmesi durumu da yasağa istisna teşkil etmektedir ${ }^{115}$.

Belirtilen istisnalar genetik ayrımcılık yasağı kapsamındadır. Bir başka deyişle istisnalar doğrultusunda elde edilen genetik bilgiler, işverenin işçilerine karşı ayrımcılık yapması için kullanılamaz ${ }^{116}$.

"Genetik Bilgileri Gizliliği” başlıklı 206. maddeye göre bir işveren, özel istihdam bürosu, çalışma örgütü bir işçi hakkında genetik bilgiye sahip ise bu bilgiler ayrı formlarda ve ayrı tıbbi dosyalarda saklamalı ve işçinin gizli tıbbi kaydı olarak değerlendirilmelidir. Düzenlemenin devamında işçinin genetik bilgilerinin işçinin (veya aile üyesi genetik hizmetleri alıyorsa aile üyesinin) yazılı talebi üzerine işçiye; araştırmanın ilgili mevzuata uygun olması durumunda, bir meslek veya sağlık araştırmacısına; bir mahkeme kararı ile genetik bilginin talep edilmesi halinde işveren, mahkeme kararında açıkça talep edilen genetik bilgiler hakkında ve mahkeme kararının, genetik bilginin ilgili olduğu işçi bilgisi olmadan güvence altına alınması durumunda işverenin, ilgili işçiyi mahkeme kararı ve bu karar uyarınca açıklanan genetik

113 Prince, Waterstone'a göre bu istisna işverenlere söz konusu kaynakları, aktif olarak arama hakk1 vermemektedir, Prince/Waterston, s. 124.

114 Genetik bilgi edinilmesi ile ilgili istisnalar arasında, işveren destekli bir sağlık programının parçası olarak genetik bilgi talep edilmesi yer almaktadır. İşveren sağlık programları, sağlıklı bir çalışanın üretken bir çalışan olduğu görüşündedir. Sağlık sigortası sağlayan ve sağlık bakım maliyetlerini düşürmek isteyen şirketler arasında giderek yaygınlaşan bu programlar, çeşitli biçimler almaktadır. Genel sağlık bilincini vurgulayan sağlık programları olduğu gibi yaşam tarzı değişikliklerini (sigarayı bırakma veya kilo kontrolü gibi) teşvik eden veya kalp hastalığı gibi spesifik hastalıkların yönetimini hedefleyen sağlık bulunmaktadır. Genetik bilgi, özellikle aile öyküsü, sunulan sağlık ve danışmanlık hizmetlerinin şekillendirilmesinde anahtar rol oynayabilir. Genetik mahremiyet ve ayrımcılık yapmama menfaatleri arasında bir dengeye sahip olan ve genetik tıbbın faydalarını teşvik eden GINA uyarınca işveren, bir işçinin genetik bilgisini gönüllü, yazılı bilgilendirilmiş rızası ile edinme yetkisine sahiptir ve bu bilginin profesyonel iş ilişkisinin sınırları dahlinde gizli kalması gerekmektedir. Katılımın gönüllü olması gerektiğinin altını çizen Eşit İstihdam Fırsatı Komisyonu, katılım teşviklerine eleştirel bir bakış sergilemekte ve işçilere aile tarihi ile ilgili soruları cevaplamaları gerekmediğinin söylenmesi hususunu vurgulamaktadır, Olick, s. 131-132.

115 Şen, s. 140.

116 Prince/Waterston, s. 125; Nemeth/Bonnette, s. 43. 
bilgiler hakkında bilgilendirmesi şartıyla mahkemeye; genetik bilginin soruşturma ile ilgili olması durumunda ilgili kamu görevlilerine; bir işçide veya işçinin aile üyelerinde bir hastalık veya rahatsızlığın ortaya çıkması ve bu hastalık veya rahatsızlığın ölüm tehlikesi içermesi ya da hayati tehlike arz eden bulaşıcı bir hastalığı ilgilendirmesi durumunda, ilgili işçiye de bilgilendirme yapılmak suretiyle halk sağlığı kurumuna bilgi verilmesi genetik bilgi gizliliği yasağına aykırılık oluşturmamaktadır.

Tanımların bulunduğu 201. maddede ilk olarak "komisyon" kavramı tanımlanmakta ve Komisyonun, 1964 tarihli İnsan Hakları Kanunu'nun 705. maddesi ile oluşturulan Eşit İstihdam Fırsat1 Komisyonu (Equal Employment Opportunity Commission-EEOC) anlamına geldiği belirtilmektedir. Eşit İstihdam Fırsatı Komisyonu, GINA'nın uygulanmasından sorumludur. Genetik ayrımcılık iddiasında bulunan işçilerin önce Komsiyona başvurmaları gerekmektedir ${ }^{117}$. GINA m. 208-d, 4'e göre Komisyon duruşma yapabilir, tanık dinleyebilir. GINA'nın atıf yaptığı 1964 tarihli İnsan Hakları Kanunu ile kurulan Komisyon, rrk, renk, din, cinsiyet (hamilelik, cinsiyet kimliği ve cinsel yönelim dâhil), ulusal köken, yaş (40 veya daha büyük), engellilik veya genetik bilgi nedeniyle iş başvurusunda bulunan kişilere veya işçilere karşı ayrımcılığ 1 yasadışı hale getiren federal yasaların uygulanmasından sorumludur. Komisyon, yasa kapsamındaki işverenlere yönelik ayrımcılık suçlamalarını soruşturma yetkisine sahiptir. Komisyon tarafından ayrımcılığın meydana geldiği tespit edilirse, taraflar arasındaki uyuşmazlık çözülmeye çalışılır. Bu konuda başarılı olunamaz ise Komisyonun dava açma yetkisi bulunmaktadır ${ }^{118}$.

117 Prince/Waterston, s. 125; Ajunwa, s. 90; Gürsel, s. 340.

118

https://www.eeoc.gov/eeoc/, (23.04.2020); Örneğin, Komisyon tarafindan 2014 y1lında New York'ta bir bakımevi olan Founders Pavilion, Inc.'e, işe başvuran kişilerin tıbbi muayeneleri esnasında aile tıbbi geçmişine ilişkin bilgi toplama iddiasıyla dava açılmıştır, Prince/Waterstone, s. 126; Komisyon 2019 yılında 284 adet karar almıştır. 160 şikayet için makul gerekçe olmadığ yönünde karar verilmiştir, 7 adet şikayette uzlaşma olumlu sonuçlandırılmıştır. Komisyonun faaliyetleriyle ilgili sayısal veriler için bkz. https://www.eeoc.gov/eeoc/statistics/enforcement/genetic.cfm, (22.04.2020); New York'ta bir bakım ve rehabilitasyon merkezine iş için başvuran kişilerden, aile tıbbi geçmişi hakkında bilgi talebi ve GINA kapsamında korunan genetik bilgi içeren tıbbi muayeneler gerçekleştirildiği iddiasıyla Komisyona başvuru yapılmıştır. Ek olarak tıbbi muayene ve soruşturmanın o işyerinde çalışan işçiler için yıllık olarak da yapıldığı ve hamile oldukları için kadın işçilere karşı olumsuz önlemler alındığı iddia edilmiştir. Uyuşmazlık idari olarak çözülemedi ve Komisyon tarafından açılan dava sonucundaki anlaşma kapsamında işveren tarafı, 370.000 dolar ödemeyi ve genetik, engellilik ve hamilelik temelli ayrımcılık vakalarını önlemek için politikalarını ve uygulamalarını değiştirmeyi kabul etti, Olick, s. 134-135; Ajunwa, s. 93. 


\section{B. TÜRK HUKUKU}

\section{Genel Olarak}

Genetik ayrımcılık yasağı ile ilgili bağlayıcılığı olan ilk uluslararası sözleşme olma niteliğini haiz 1997 tarihli İnsan Hakları ve İnsan Haysiyetinin Korunması Sözleşmesi: İnsan Hakları ve Biyotıp Sözleşmesi Türkiye tarafından da kabul edilmiştir ve Sözleşme, 2004 yılında ülkemizde yürürlüğe girmiştir. Yukarıda da ifade edildiği üzere genetik ayrımcılık, Biyotıp Sözleşmesi ile yasaklanmış olup, söz konusu yasak İş Hukuku için de şüphesiz geçerlidir. Söz konusu hüküm, genetik ayrımcılığı açıç̧a yasaklayan mevzuatımızdaki tek düzenlemedir.

İşverenin iş sözleşmesinden doğan borçları arasında eşit davranma yükümlülügü de yer almaktadır. İş Hukukunda eşitlik ilkesinin yasal dayanakları Anayasanın 10. maddesi, İş Kanununun ${ }^{119}$ 5. maddesi ve 6701 sayılı Türkiye İnsan Hakları ve Eşitlik Kurumu Kanunu ${ }^{120}$, dur ${ }^{121}$.

$119 \quad 10.06 .2003,25134$.

120 RG. 20.04.2016, 29690.

121 Çelik, Nuri/Caniklioğlu, Nurșen/Canbolat, Talat: İş Hukuku Dersleri, Yenilenmiş 32. Bası, Beta Yayıncılık, İstanbul, 2019, s. 414; Akyiğit, Ercan: İş Hukuku, 11. Basım, Seçkin Yayıncılık, İstanbul, 2016, s. 235; Senyen Kaplan, E. Tuncay: "İş Hukukunda Eşitlik İlkesi ve Ayrımcılık Yasağı”, Türkiye Barolar Birliği Dergisi, Özel Sayı, 2017, s. 226; Ekmekçi, Ömer/Yiğit, Esra: Bireysel İş Hukuku Dersleri, On İki Levha Yayıncılık, İstanbul, 2020, s. 276; İşverenin eşit davranma borcu hakkında bkz. Tuncay, A. Can: İş Hukukunda Eşit Davranma İlkesi, Fakülteler Matbaası, İstanbul, 1982, s. 5 vd; Çelik, Nuri: "İş̧̧ilerin İş̧en Çıkarılmalarında İhbar ve Kıdem Tazminatları Dışında İsteyebilecekleri Tazminatlara İlişkin Sorunlar", Legal İş Hukuku ve Sosyal Güvenlik Hukuku Dergisi, Cilt 4, Sayı 14, 2007, s. 5 vd; Süzek, Sarper: "İşverenin Eşit Davranma Borcu", Sicil İş Hukuku Dergisi, Sayı 12, 2008, s. 24 vd; Ertürk, Şükran: İş İlişkisinde Temel Haklar, Seçkin Yayıncılık, Ankara, 2002, s. 94 vd; Keser, Hakan: "4857 Sayılı İş Kanununa Göre İşverenin İş Sözleşmesi Yapma ve İş İlişkilerinde Eşit İşlem Yapma Yükümlülükleri ve Bunlara Aykırı Davranılması Durumunda Karşılaşacağı Yaptırımlar”, Yargıç Resul Aslanköylü’ye Armağan, Kamu-İs, Cilt 7, Sayı 53, 2004, s. 23; Ulucan, Devrim: "Eşitlik İlkesi ve Pozitif Ayrımcılık Yasağı, Dokuz Eylül Üniversitesi Hukuk Fakültesi Dergisi, Cilt 15, Özel Sayı, 2013, s. 372 vd; Doğan Yenisey, Kübra: "Eşit Davranma İlkesinin Uygulanmasında Metodoloji ve Orantıllık, Legal İş Hukuku ve Sosyal Güvenlik Hukuku Dergisi, Cilt 2, Sayı 7, 2005, s. 974 vd; Doğan Yenisey, Kübra: "İş Kanununda Eşitlik İlkesi ve Ayrımcılık Yasağı", Çalışma ve Toplum, Cilt 4, Sayı 11, 2006, s. 64 vd; Odaman, Serkan: "Ayrımcılık Tazminatının Diğer Tazminatlarla Birlikte Mevcudiyeti Üzerine Görüşler”, Sicil İş Hukuku Dergisi, Sayı 14, 2009, s. 78 vd; Yıldız, Gaye Burcu: İşverenin Eşit İşlem Yapma Borcu, Yetkin Yayıncılık, Ankara, 2008, s. 60 vd; Yıldız, Gaye Burcu: "İş Sözleşmesinin Feshinde Eşit İ̧̧lem Yapma Borcu ve Ayrımcılık Yasağı", Prof. Dr. Ali Güzel'e Armağan Cilt I, İstanbul, 2010, s. 837 vd; Demir, Fevzi: "İşverenin Eşit İşlem Yapma Borcu ve Ayrım Yasağ 
Anayasanın 10. maddesinin ilk iki fikrası uyarınca herkes, dil, ırk, renk, cinsiyet, siyasi düşünce, felsefi inanç, din, mezhep ve benzeri sebeplerle ayırım gözetilmeksizin kanun önünde eşittir. Kadınlar ve erkekler eşit haklara sahiptir. Devlet, bu eşitliğin yaşama geçmesini sağlamakla yükümlüdür. $\mathrm{Bu}$ maksatla alınacak tedbirler eşitlik ilkesine aykırı olarak yorumlanamaz. Belirtilen hükümde hem ayrım yapma yasağı hem de genel anlamda eşit davranma borcu düzenlenmektedir ${ }^{122}$. İş Kanununun 5. maddesinde de "Eşit davranma ilkesi" başlığ ${ }_{1}$ altında ayrımcılık yasağı kural altına alınmıştır ${ }^{123}$. Buna göre "İş ilişkisinde dil, 1rk, renk, cinsiyet, engellilik, siyasal düşünce, felsefî inanç, din ve mezhep ve benzeri sebeplere dayalı ayrım yapılamaz" (f. 1). Belirtelim ki hem Anayasanın 10. maddesinde hem de İş Kanunu m. 5 'de sayılan ayrımcılık sebepleri sınırlı sayım esası ile tüketilmemiştir ${ }^{124}$. Söz konusu düzenlemelerde "ve benzeri sebeplere dayalı ${ }^{125 "}$ denilmek suretiyle

Tazminatının Diğer Tazminatlarla İlişkisi”, Legal İş Hukuku ve Sosyal Güvenlik Hukuku Dergisi, Cilt 11, Sayı 41, 2014, s. 16 vd; Sur, Melda: "İş İlişkisinde Eşitlik İlkesi ve Ayrımcıllk Yasağı", Sicil İş Hukuku Dergisi, Sayı 37, 2017, s. 34 vd; SenyenKaplan, Eşitlik, s. 227 vd; Kandemir, Murat/Yardımcıoğlu, Didem: "İş Hukukunda Eşitlik İlkesi”, Dicle Üniversitesi Hukuk Fakültesi Dergisi, Cilt 19, Sayı 30-31, 2004, s. 4 vd; Baysal, Ulaş: "İşverenin Eşit Davranma Borcu ve İş Sözleşmesinin Feshinde Uygulanması", Legal İş Hukuku ve Sosyal Güvenlik Hukuku Dergisi, Cilt 7, Sayı 25, 2010, s. 61 vd; Ertürk, Şükran/Gürsel, İlke: "İş Hukukunda Eşit Davranma İlkesi", Prof. Dr. Sarper Süzek'e Armağan C. I, Beta Yayınc1lı, İstanbul, 2011, s. 425 vd; Nazlı, Seçkin: "İş Kanunu'nda Düzenlenen Eşit Davranma İlkesi ve Uygulama Sorunları Üzerine Değerlendirmeler", İstanbul Üniversitesi Hukuk Fakültesi Mecmuası (Prof. Dr. Fevzi Şahlanan'a Armağan), Cilt I, Özel Sayı, 2016, s. 571 vd; Doğan, Sevil: "Türk İş Hukukunda Eşitlik İlkesinin Anlamı", Türkiye Adalet Akademisi Dergisi, Sayı 9, 2012, s. 178 vd; Ünal, Canan: İş Hukukunda Yaş Ayrımcılı̆̆ı, On İki Levha Yayınc1lı, İstanbul, 2018, s. 53 vd.

122 Süzek, Sarper: İş Hukuku, Yenilenmiş 18. Baskı, Beta Yayıncılık, İstanbul, 2019, s. 440-441; Çelik/Caniklioğlu/Canbolat, s. 415; Süzek, Eşit Davranma, s, 25; Sur, s. 35; İnceoğlu, Sibel: "Türk Anayasa Mahkemesi ve İnsan Hakları Avrupa Mahkemesi Kararlarında Eşitlik ve Ayrımcılık Yasağı", Çalışma ve Toplum, Cilt 4, Sayı 11, 2006, s. 48-49; Kandemir/Yardımcıoğlu, s. 7-8; Yıldız, Ayrımcılık, s. 840; Doğan, s. 180.

123 Süzek, s. 441; Süzek, Eşit Davranma, s. 25; Doğan Yenisey, Metodoloji, s. 976; Doğan Yenisey, s. 63 vd; Sur, s. 39; Ertürk/Gürsel, s. 431; Kandemir/Yardımcioğlu, s. 8; Yıldız, Ayrımcılık, s. 838; Nazlı, s. 572; Doğan, s. 182.

124 Süzek, s. 441; Çelik/Caniklioğlu/Canbolat, s. 415; Tunçomağ, Kenan/Centel, Tankut: İş Hukukunun Esasları, 9. Bask1, İstanbul: Beta Yayıncılık, 2018, s. 146; Doğan Yenisey, Metodoloji, s. 978; Bakırcı, Kadriye: "Eşitlik Kurulu Kanunu ile Anayasa ve İş Kanunu'nun İlgili Hükümleri Üzerine Bir Değerlendirme”, (Ed. Necdet Basa, Sema Uçakhan Güleç), Emeğin Hukuku Kurultayı 2, Türkiye Barolar Birliği Yayını, Ankara, 2017, s. 74; Yıldız, Ayrımcilık, s. 838; Baysal, s. 71.

125 Düzenlemedeki "ve benzeri sebepler" ifadesi kişi temel hak ve özgürlükleri çerçevesinde değerlendirilmelidir, Doğan Yenisey, Eşitlik, s. 65. 
fikrada sayılan sebeplerin sinırlı olmadığı ortaya konulmuş olduğu için örneğin cinsel eğilim ya da yaş ${ }^{126}$ yahut genetik bilgi nedeniyle yapılan ayrımcılıklar da belirtilen maddelerin kapsamında değerlendirilecektir ${ }^{127}$. Daha açık deyişle genetik ayrımcılık yasağının yasal dayanağının Anayasanın 10. maddesinin ve İş Kanununun 5. maddesinin olduğunu ifade edebiliriz.

Ayrımcılık yasağı ile ilgili bir diğer pozitif dayanak olan 6701 sayılı Türkiye İnsan Hakları ve Eşitlik Kurumu Kanununun "Eşitlik ilkesi ve ayrımcılık yasağı" başlıklı 3. maddesinin 1. fikrasında herkesin, hukuken tanınmış hak ve hürriyetlerden yararlanmada eşit olduğu; 2. fikrasında ise bu Kanun kapsamında cinsiyet, ırk, renk, dil, din, inanç, mezhep, felsefi ve siyasi görüş, etnik köken, servet, doğum, medeni hâl, sağlik durumu, engellilik ve yaş temellerine dayalı ayrımcılığın yasak olduğu ifade edilmiştir. Ancak belirtilen hükümde ayrımcılık yasağı, düzenlemede sıralanan ayrımc1lık sebepleri ile sinırlı tutulduğu için ${ }^{128}$ genetik ayrımcılık yasağı, 6701 sayılı Türkiye İnsan Hakları ve Eşitlik Kurumu Kanunu kapsamında yer almamaktadır. Bu noktada ayrımcılık sebepleri arasında "sağlık durumu"nun bulunması dikkat çekmekte ve bir kişinin sağlık bilgisi ile genetik bilgisi örtüşür mü yahut sağlık bilgisi bakımından ayrımcılık yasağının getirilmesi genetik ayrımcılık yasağı bakımından ayrı bir düzenleme ihtiyacının önüne geçer mi sorularını sorma ihtiyacı doğmaktadır. Genetik bilginin kapsamında, kişinin sağlığıyla ilgili bilgileri de bulunmaktadır. Bununla birlikte kişinin saçının rengini belirleyen genetik bilgi örneğinde olduğu üzere genetik bilginin, doğrudan sağlıkla ilgili olmadığı durumlar da mevcut olduğu için genetik bilgi ile sağlık bilgisi tam olarak örtüşmemektedir ${ }^{129}$. Genetik bilgi ile sağlık bilgisi ilişkisi doktrinde "genetik müstesnalık" (genetic exceptionalism) başlığ 1 altında incelenmektedir ${ }^{130}$. Genetik müstesnalık kavramına göre genetik bilgi, sağlı bilgisi ve diğer bilgilerden daha has-

126 Bkz. Ünal, s. 55 vd; Ünal, Canan: "Yaş Ayrımcıllı̆̆ Kapsamında İş Sözleşmesinin Sona Ermesinde Yaş ve Emekliliğin Değerlendirilmesi”, İş Hukukunda Yeni Yaklaşımlar (Ed. Kübra Doğan Yenisey, Seda Ergüneş Emrağ), Beta Yayınc1lık, İstanbul, 2017, s. 313 vd. Çelik/Caniklioğlu/Canbolat, s. 415; Süzek, Eşit Davranma, s. 25-26; Senyen-Kaplan, Eşitlik, s. 236; Ertürk/Gürsel, s. 434-435. Çelik/Caniklioğlu/Canbolat, s. 417; Bakırcı, s. 74; Sur, s. 37. https://ec.europa.eu/justice/article-29/documentation/opinionrecommendation/files/ 2004/wp91_en.pdf, s. 5.

130 Küzeci, s. 97; Genetik müstesnalık kavramını geliştiren kişi olan Thomas H. Murray günümüzde, genetik müstesnalık kavramından uzaklaşılması gerektiği yönündeki görüşe katıldığını ifade etmektedir. Bkz. Murray, Thomas H.: "Is Genetic Exceptionalism Past Its Sell-By Date? On Genomic Diaries, Context, and Content", The American Journal of Bioethics, Cilt 19, Sayı 1, 2019, s. 13 vd. 
sastır ve onlardan ayrı olarak ele alınmalıdır ${ }^{131}$. Kanaatimizce, genetik bilginin kötüye kullanılmasının önüne geçilmesi için "genetik bilgi" temelli ayrımcılığın ayrıca kural altına alınması gerekmektedir. Belirtilen gerekliliğe, daha önce değindiğimiz, 6698 sayılı Kanunda özel nitelikli kişisel verilerin sıralandığı m. 6/1 örnek olarak verilebilir. Şöyle ki söz konusu hükümde, sağlık verileri de genetik veriler de özel nitelikli kişisel veri olarak belirtilmektedir. Bir başka deyişle yasal olarak korunabilmeleri için sağlık bilgisi de genetik bilgi de ayrıca hükme bağlanmıştır.

\section{Kişisel Verilerin Korunması Bakımından Değerlendirme}

Genetik bilginin kişisel veri olduğunu daha önce de ifade etmiştik. Mevzuatımızdaki kişisel verilerin korunması ile ilgili hükümler, kişisel veri niteliğindeki genetik bilgi için de geçerli olacaktır ${ }^{132}$. Kişisel verilerin korunması hakkının hukuki dayanaklarının başında Anayasanın özel hayatın gizliliğini düzenleyen m. 20/3 hükmü yer almaktadır. Buna göre, "Herkes, kendisiyle ilgili kişisel verilerin korunmasını isteme hakkına sahiptir. $\mathrm{Bu}$ hak; kişinin kendisiyle ilgili kişisel veriler hakkında bilgilendirilme, bu verilere erişme, bunların düzeltilmesini veya silinmesini talep etme ve amaçları doğrultusunda kullanılıp kullanılmadığını öğrenmeyi de kapsar. Kişisel veriler, ancak kanunda öngörülen hallerde veya kişinin açık rızasıyla işlenebilir. Kişisel verilerin korunmasına ilişkin esas ve usuller kanunla düzenlenir".

İş Kanununun "İş̧i özlük dosyası" başlıklı 75. maddesi de kişisel verilerin saklanmasına ilişkin özel bir düzenlemedir. Anılan maddenin 1. fikra-

\footnotetext{
131 Küzeci, s. 97.

132 İşçinin kişisel verilerinin korunması hakkında bkz. Süzek, s. 391 vd; Çelik/Caniklioğlu/ Canbolat, s. 362 vd; Mollamahmutoğlu, Hamdi/Astarlı, Muhittin/Baysal, Ulaş: İş Hukuku, Gözden Geçirilmiş ve Genişletilmiş 6. Bası, Turhan Kitabevi, Ankara, 2014, s. 717 vd; Senyen-Kaplan, E. Tuncay: Bireysel İş Hukuku, Yenilenmiş 10. Baskı, Gazi Kitabevi, Ankara, 2019, s. 195 vd; Okur, Zeki: "Türk İş Hukukunda İşçinin Kişisel Verilerinin Korunması Hakkı", İş Dünyası ve Hukuk: Prof. Dr. Tankut Centel'e Armağan, İstanbul Üniversitesi Yayınları, İstanbul, 2011, s. 368 vd; Manav, s. 99 vd; Gürsel, s. 157 vd; Gürsel, İlke: "Kişisel Verilerin Korunması Hakkının İşçi ve İşveren İlişkilerine Etkileri”, Legal İş Hukuku ve Sosyal Güvenlik Hukuku Dergisi, Sayı 50, 2016, s. 764 vd; Bozkurt Gümrükçüoğlu, Yeliz: "İ̧ İlişkisinde Kişisel Verilerin Korunmasına İlişkin Sorunlar ve Kişisel Verilerin Korunması Kanunu”, (Ed. Kübra Doğan Yenisey, Seda Ergüneş Emrăg), İş Hukukunda Yeni Yaklaşımlar, Beta Yayınc1lık, İstanbul, 2017, s. 19 vd; Ünal, Canan: "İş Sözleşmesinin Kurulmasında Sağlığa İlişkin Veriler”, (Ed. Tankut Centel), İş Hukukunda Genç Yaklaşımlar III, On İki Levha Yayınc1lık, İstanbul, 2018, s. 261 vd; Küzeci, Kişisel Veri, s. 17 vd.
} 
sına göre işveren çalıştırdığı her işçi için bir özlük dosyası düzenler. İşveren bu dosyada, işçinin kimlik bilgilerinin yanında, bu Kanun ve diğer kanunlar uyarınca düzenlemek zorunda olduğu her türlü belge ve kayıtları saklamak ve bunları istendiği zaman yetkili memur ve mercilere göstermek zorundadır. Hükmün 2. fikrasında da işverene, işçi hakkında edindiği bilgileri dürüstlük kuralları ve hukuka uygun olarak kullanmak ve gizli kalmasında işçinin haklı çıkarı bulunan bilgileri açıklamama yükümlülüğü getirilmektedir. İşverenin işçiye ait kişisel verileri, ancak işçinin işe yatkınlığıyla ilgili veya hizmet sözleşmesinin ifası için zorunlu olduğu ölçüde kullanabileceğine ilişkin Türk Borçlar Kanununun ${ }^{133}$ 419. maddesi de konuya ilişskin bir başka yasal dayanaktır.

Genetik bilgi, sağlıkla ilgili verilerden daha geniş kapsamlı olmakla birlikte sağl1kla ilgili verilerin içeriğinde, genetik bilgilerin olma ihtimaline binaen 6331 sayılı İş Sağlığı ve Güvenliği Kanununda ${ }^{134}$ yer alan sağlık verilerin korunması ile ilgili düzenlemeye de değinmek gerekmektedir. Buna göre "Sağlık muayenesi yaptırılan çalışanın özel hayatı ve itibarının korunması açısından sağlık bilgileri gizli tutulur" (m. 15/5).

Konuyla ilgili detaylı düzenleme niteliğini haiz olan 6698 sayılı Kanun incelendiğinde genetik bilginin özel nitelikli kişisel veri olarak nitelendirildiğini daha önce belirtmiştik. 6698 sayılı Kanuna göre özel nitelikli kişisel verilerin, ilgilinin açık rızası olmaksızın işlenmesi yasaktır (m. 6/1). Kişisel verilerin işlenmesi, kişisel verilerin tamamen veya kısmen otomatik olan ya da herhangi bir veri kayıt sisteminin parçası olmak kaydıyla otomatik olmayan yollarla elde edilmesi, kaydedilmesi, depolanması, muhafaza edilmesi, değiştirilmesi, yeniden düzenlenmesi, açıklanması, aktarılması, devralınması, elde edilebilir hâle getirilmesi, sınıflandırılması ya da kullanılmasının engellenmesi gibi veriler üzerinde gerçekleştirilen her türlü işlemdir (m. 3/1e). Bir başka deyişle kişisel verilerin işlenmesi, kişiye ait kişisel verilerin toplanması, saklanması, birleştirilmesi, iletilmesi veya diğer her türlü kullanımını kapsama alan işlem veya işlemler topluluğudur ${ }^{135}$. Özel nitelikli kişisel verilerin işlenmesi ile ilgili Kanunun 6. maddesinin 3. fikrasına göre, sağlık ve cinsel hayat dışındaki kişisel veriler, kanunlarda öngörülen hâllerde ilgili kişinin açık rızası aranmaksızın işlenebilir. Belirtilen düzenlemeler ile genetik bilgilerin işveren tarafından, işçinin açık rızası olmaksızın işlenmesinin yasak olduğu ve fakat kanunlarda öngörülen hallerde ilgili işçinin açık

133 RG. 04.02.2011, 27836.

134 RG. $30.06 .2012,28339$.

135 Gürsel, s. 203; Gürsel, Etki, s. 782; Çelik/Caniklioğlu/Canbolat, s. 367. 
rızası aranmadan da genetik bilginin işlenebileceği sonucuna varılmaktadır. Açık rıza, ilgili işçinin konuya ilişkin bilgilendirilmesine dayanan ve özgür iradesiyle baskı altında kalmadan açıladığı rıza şeklinde açıklanabilir ${ }^{136}$.

6698 sayılı Kanunda yer alan hakları incelemeye devam etmeden önce "veri sorumlusu", "veri işleyen" ve "ilgili kişi” kavramlarını tanımlamak gerekmektedir. Kanunun 3. maddesine göre veri sorumlusu, kişisel verilerin işleme amaçlarını ve vasıtalarını belirleyen, veri kayıt sisteminin kurulmasından ve yönetilmesinden sorumlu olan gerçek veya tüzel kişiyi; veri işleyen, veri sorumlusunun verdiği yetkiye dayanarak onun adına kişisel verileri işleyen gerçek veya tüzel kişiyi; ilgili kişi ise kişisel verisi işlenen gerçek kişiyi ifade etmektedir. İş ilişkilerinde kişisel bilgileri işlenen işçi ilgili kişi, veri sorumlusu gerçek veya tüzel kişi işveren, veri işleyen ise sıklıkla işyerinde çalışan insan kaynakları yetkilisi, işyeri hekimi gibi bir diğer işçi olacaktır ${ }^{137}$. Bununla birlikte işyeri dışından başka bir kişi ya da tüzel kişi de veri işleyen olarak yetkilendirilebiliri ${ }^{138}$.

"Veri sorumlusunun aydınlatma yükümlülüğü" başlıklı Kanunun 10. maddesine göre kişisel verilerin elde edilmesi sırasında veri sorumlusu veya yetkilendirdiği kişi, ilgili kişilere; a) Veri sorumlusunun ve varsa temsilcisinin kimliği, b) Kişisel verilerin hangi amaçla işleneceği, c) İşlenen kişisel verilerin kimlere ve hangi amaçla aktarılabileceği, ç) Kişisel veri toplamanın yöntemi ve hukuki sebebi, d) 11. maddede sayılan diğer hakları konusunda bilgi vermekle yükümlüdür. "İlgili kişinin hakları" başlıklı Kanunun 11. maddesine göre herkes, veri sorumlusuna başvurarak kendisiyle ilgili; a) Kişisel veri işlenip işlenmediğini öğrenme, b) Kişisel verileri işlenmişse buna ilişkin bilgi talep etme, c) Kişisel verilerin işlenme amacını ve bunların amacına uygun kullanılıp kullanılmadığını öğrenme, ç) Yurt içinde veya yurt dışında kişisel verilerin aktarıldığ 1 üçüncü kişileri bilme, d) Kişisel verilerin eksik veya yanlış işlenmiş olması hâlinde bunların düzeltilmesini isteme, e) Kanunun 7. maddesinde ${ }^{139}$ öngörülen şartlar çerçevesinde kişisel verilerin

136 Bozkurt Gümrükçüoğlu, s. 56; Senyen-Kaplan, s. 199.

137 Çelik/Caniklioğlu/Canbolat, s. 369-370; Bozkurt Gümrükçüoğlu, s. 28; Gürsel, Etki, s. 778 .

138 Çelik/Caniklioğlu/Canbolat, s. 370.

1396698 sayılı Kanunun 7. maddesine göre "(1) Bu Kanun ve ilgili diğer kanun hükümlerine uygun olarak işlenmiş olmasına rağmen, işlenmesini gerektiren sebeplerin ortadan kalkması hâlinde kişisel veriler resen veya ilgili kişinin talebi üzerine veri sorumlusu tarafindan silinir, yok edilir veya anonim hâle getirilir. (2) Kişisel verilerin silinmesi, yok edilmesi veya anonim hâle getirilmesine ilişkin diğer kanunlarda yer alan hükümler saklıdır. (3) Kişisel verilerin silinmesine, yok edilmesine veya anonim hâle getirilmesine ilişkin usul ve esaslar yönetmelikle düzenlenir". 
silinmesini veya yok edilmesini isteme, f) (d) ve (e) bentleri uyarınca yapılan işlemlerin, kişisel verilerin aktarıldığ üçüncü kişilere bildirilmesini isteme, g) İşlenen verilerin münhasıran otomatik sistemler vasıtasıyla analiz edilmesi suretiyle kişinin kendisi aleyhine bir sonucun ortaya çıkmasına itiraz etme, $\breve{g}$ ) Kişisel verilerin kanuna aykırı olarak işlenmesi sebebiyle zarara uğraması hâlinde zararın giderilmesini talep etme haklarına sahiptir.

Yine "Veri güvenliğine ilişkin yükümlülükler" başlıklı Kanunun 12. maddesine göre veri sorumlusu; a) Kişisel verilerin hukuka aykırı olarak işlenmesini önlemek, b) Kişisel verilere hukuka aykırı olarak erişilmesini önlemek, c) Kişisel verilerin muhafazasını sağlamak, amacıyla uygun güvenlik düzeyini temin etmeye yönelik gerekli her türlü teknik ve idari tedbirleri almak zorundadır (f. 1). Veri sorumlusu, kişisel verilerin kendi adına başka bir gerçek veya tüzel kişi tarafından işlenmesi hâlinde, birinci fikrada belirtilen tedbirlerin alınması hususunda bu kişilerle birlikte müştereken sorumludur (f. 2). Veri sorumlusu, kendi kurum veya kuruluşunda, bu Kanun hükümlerinin uygulanmasını sağlamak amacıyla gerekli denetimleri yapmak veya yaptırmak zorundadır (f. 3). Veri sorumluları ile veri işleyen kişiler, öğrendikleri kişisel verileri bu Kanun hükümlerine aykırı olarak başkasına açıklayamaz ve işleme amacı dışında kullanamazlar. Bu yükümlülük görevden ayrılmalarından sonra da devam eder (f. 4). İşlenen kişisel verilerin kanuni olmayan yollarla başkaları tarafından elde edilmesi hâlinde, veri sorumlusu bu durumu en kısa sürede ilgilisine ve Kurula ${ }^{140}$ bildirir. Kurul,

1406698 sayılı Kanunun 21. maddesinin 1. fikrasına göre Kişisel Verileri Koruma Kurulu, bu Kanunla ve diğer mevzuatla verilen görev ve yetkilerini kendi sorumluluğu altında, bağımsız olarak yerine getirir ve kullanır. Görev alanına giren konularla ilgili olarak hiçbir organ, makam, merci veya kişi, Kurula emir ve talimat veremez, tavsiye veya telkinde bulunamaz. Kurulun görev ve yetkileri Kanunun 22. maddesinde sıralanmıştır. Buna göre "a) Kişisel verilerin, temel hak ve özgürlüklere uygun şekilde işlenmesini sağlamak. b) Kişisel verilerle ilgili haklarının ihlal edildiğini ileri sürenlerin şikâyetlerini karara bağlamak. c) Şikâyet üzerine veya ihlal iddiasını öğrenmesi durumunda resen görev alanına giren konularda kişisel verilerin kanunlara uygun olarak işlenip işlenmediğini incelemek ve gerektiğinde bu konuda geçici önlemler almak. ç) Özel nitelikli kişisel verilerin işlenmesi için aranan yeterli önlemleri belirlemek. d) Veri Sorumluları Sicilinin tutulmasını sağlamak. e) Kurulun görev alanı ile Kurumun işleyişine ilişkin konularda gerekli düzenleyici işlemleri yapmak. f) Veri güvenliğine ilişkin yükümlülükleri belirlemek amacıyla düzenleyici işlem yapmak. g) Veri sorumlusunun ve temsilcisinin görev, yetki ve sorumluluklarına ilişkin düzenleyici işlem yapmak. ğ) Bu Kanunda öngörülen idari yaptırımlara karar vermek. h) Diğer kurum ve kuruluşlarca hazırlanan ve kişisel verilere ilişkin hüküm içeren mevzuat taslakları hakkında görüş bildirmek. 1) Kurumun; stratejik planını karara bağlamak, amaç ve hedeflerini, hizmet kalite standartlarını ve performans kriterlerini belirlemek. i) Kurumun stratejik planı ile amaç ve hedeflerine uygun olarak hazırlanan bütçe teklifini görüşmek ve karara bağlamak. 
gerekmesi hâlinde bu durumu, kendi internet sitesinde ya da uygun göreceği başka bir yöntemle ilan edebilir (f. 5).

İşçinin genetik bilgisinin kişisel veri olması hasebiyle yukarıda belirtilen kişisel verileri işlenen kişiye ait haklar, genetik bilgisi işlenen işçiler için de geçerlidir.

6698 sayılı Kanunda kişisel verisi işlenen kişilere, Kanunun uygulanmasıyla ilgili taleplerini yazılı olarak veri sorumlusuna iletme hakkı da düzenlenmektedir. Veri sorumlusunun başvuruda yer alan talepleri, talebin niteliğine göre en kısa sürede ve en geç otuz gün içinde ücretsiz olarak sonuçlandırması gerekmektedir. Veri sorumlusu talebi kabul eder veya gerekçesini açıklayarak reddeder ve cevabını ilgili kişiye yazılı olarak veya elektronik ortamda bildirir. Başvuruda yer alan talebin kabul edilmesi hâlinde veri sorumlusunca gereği yerine getirilir (m 13). Başvurunun reddedilmesi, verilen cevabın yetersiz bulunması veya süresinde başvuruya cevap verilmemesi hâllerinde; ilgili kişi, veri sorumlusunun cevabını öğrendiği tarihten itibaren otuz ve her hâlde başvuru tarihinden itibaren altmış gün içinde Kurula şikâyette bulunabilecektir. Kurula şikâyette bulunabilmek için veri sorumlusuna başvuru yolunun tüketilmesi gerekmektedir (m. 14). Ancak ilgili kişinin, konumuz bakımından genetik bilgisi işlenen iş̧̧inin, hak ihlallerine yönelik olarak doğrudan yargıya organlarına başvurmasının önünde herhangi bir engel bulunmamaktadır. Diğer bir ifadeyle, konunun yargıya intikal ettirilmesinden önce iş̧̧inin veri sorumlusuna başvurma zorunluluğu bulunmamaktadır ${ }^{141}$.

İşverenin işçinin genetik bilgilerini hukuka aykırı olarak işlemesi durumunda 6698 sayılı Kanunda, işçinin bu davranış nedeniyle zarara uğraması

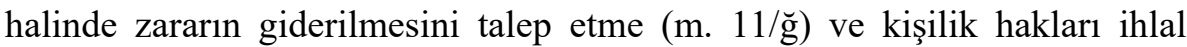
edilen işçinin genel hükümler uyarınca tazminat hakkının saklı olduğu (m. 14/3) hüküm altına alınmaktadır ${ }^{142}$. Kişilik hakkı zedelenen işçi bakımından, genel hükümlerde ve iş mevzuatında iş̧̧inin kişiliğinin korunmasına ilişkin müeyyidelerin kişisel verilerin korunmasında da uygulanacağına şüphe bulunmamaktadır ${ }^{143}$. Ayrıca, İş Kanunu m. 24/II doğrultusunda işverenin davranışı, ahlak ve iyiniyet kurallarına aykırı nitelikte olduğu için işçinin iş

j) Kurumun performansı, mali durumu, yıllık faaliyetleri ve ihtiyaç duyulan konular hakkında hazırlanan rapor taslaklarını onaylamak ve yayımlamak. k) Taşınmaz alımı, satımı ve kiralanması konularındaki önerileri görüşüp karara bağlamak. 1) Kanunlarla verilen diğer görevleri yerine getirmek".

141 Çelik/Caniklioğlu/Canbolat, s. 372.

142 Süzek, s. 395; Çelik/Caniklioğlu/Canbolat, s. 373.

143 Süzek, s. 395; Çelik/Caniklioğlu/Canbolat, s. 373. 
sözleșmesini haklı nedenle feshetme hakkı da bulunmaktadır ${ }^{144}$. Ek olarak 6698 sayılı Kanunun $17^{145}$. ve $18^{146}$. maddelerinde işverene uygulanacak cezai ve idari yaptırımlar kural altına alınmaktadır.

\section{Genetik Ayrımcılık Yasağı ile İlgili Ayrı Düzenleme Gerekliliği}

Doktrinde Paor ve Ferri genetik bilginin, kişisel veri bağlamında korunmasını eksik bulmaktadır. Şöyle ki kişisel verinin korunması kapsamında işçinin genetik bilgisine erişimi ve genetik bilgisini açıklamamayı kapsamına alan bir gizlilik yaklaşımı, genetik bilginin ayrımcı kullanımını engellemek için yetersiz kalacaktır. Sadece gizlilik yaklaşımı ile genotipi veya spesifik bir genetik kusuru nedeniyle bir işçiye, daha dezavantajlı bir şekilde muamele edilme potansiyeli engellenemez. Nitekim yine bu yaklaşımda işveren, ilgili işçiden onay alarak da genetik bilgilere erişebilir. Hâlbuki genetik bilgi temelli ayrımcılığın yasaklanması ile bir işçinin genetik bilgisi nedeniyle olumsuz veya haksız muameleye maruz kalması önlenebilecektir. Öte yandan genetik ayrımcılık yasağı, toplumsal açıdan da genetik bir alt sınıfın oluşumunu, bir başka deyişle genetik olarak istenmeyen bireylerin toplumun dışına itilmesini engelleme amacına da hizmet edecektir. Paor, Ferri tarafından bu doğrultuda, Avrupa Birliği için genetik ayrımcılık yasağı ile ilgili ayrı yönerge önerisinde bulunmaktadır ${ }^{147}$.

144 Çelik/Caniklioğlu/Canbolat, s. 373; Mollamahmutoğlu/Astarlı/Baysal, s. 720.

1456698 sayılı Kanunun 17. maddesine göre "(1) Kişisel verilere ilişkin suçlar bakımından 26/9/2004 tarihli ve 5237 sayılı Türk Ceza Kanununun 135 ila 140 incı madde hükümleri uygulanır. (2) $\mathrm{Bu}$ Kanunun 7 nci maddesi hükmüne aykırı olarak; kişisel verileri silmeyen veya anonim hâle getirmeyenler 5237 sayılı Kanunun 138 inci maddesine göre cezalandırılır".

1466698 sayılı Kanunun 18. maddesine göre “(1) Bu Kanunun; a) 10 uncu maddesinde öngörülen aydınlatma yükümlülüğ̈̈nü yerine getirmeyenler hakkında 5.000 Türk lirasından 100.000 Türk lirasına kadar, b) 12 nci maddesinde öngörülen veri güvenliğine ilişkin yükümlülükleri yerine getirmeyenler hakkında 15.000 Türk lirasından 1.000.000 Türk lirasına kadar, c) 15 inci maddesi uyarınca Kurul tarafindan verilen kararları yerine getirmeyenler hakkında 25.000 Türk lirasından 1.000.000 Türk lirasına kadar, ç) 16 ncı maddesinde öngörülen Veri Sorumluları Siciline kayıt ve bildirim yükümlülüğüne aykırı hareket edenler hakkında 20.000 Türk lirasından 1.000.000 Türk lirasına kadar, idari para cezası verilir. (2) Bu maddede öngörülen idari para cezaları veri sorumlusu olan gerçek kişiler ile özel hukuk tüzel kişileri hakkında uygulanır. (3) Birinci fikrada sayılan eylemlerin kamu kurum ve kuruluşları ile kamu kurumu niteliğindeki meslek kuruluşları bünyesinde işlenmesi hâlinde, Kurulun yapacağı bildirim üzerine, ilgili kamu kurum ve kuruluşunda görev yapan memurlar ve diğer kamu görevlileri ile kamu kurumu niteliğindeki meslek kuruluşlarında görev yapanlar hakkında disiplin hükümlerine göre işlem yapılır ve sonucu Kurula bildirilir".

147 Paor/Ferri, s. 27-28; Konu hakkında ayrıca bkz. Gürsel, s. 337 vd. 
Genetik ayrımcılık yasağı ile ilgili ayrı bir düzenleme gerekliliğini destekleyen bir diğer nokta, 6331 sayılı Kanun kapsamında işverenin sağl1k gözetimi yükümlülügüüür. 6331 sayılı Kanunun 15. maddesi uyarınca işveren, çalışanların işyerinde maruz kalacakları sağlık ve güvenlik risklerini dikkate alarak sağlık gözetimine tabi tutulmalarını sağlamak zorundadır. Bu doğrultuda çalışanların işe girişlerinde, belirli aralıklarla ve Kanunda belirtilen diğer hallerde çalışanlara sağlık muayenesi yapılmaktadır ${ }^{148}$. İşverenin sağlık muayenesi yaptırma yükümlülüğü ile ilgili olarak kişilerin, sağlık muayenesi sonucunda elde edilen (genetik) bilgileri doğrultusunda ayrımcılığa maruz kalma korkusu yaşamaları dikkate alınması gereken bir ihtimaldir ${ }^{149}$. İşverenlerin sağlık gözetimi yükümlülüğü ile ilgili olan İşyeri Hekimi ve Diğer Sağlık Personelinin Görev, Yetki, Sorumluluk ve Eğitimleri Hakkında Yönetmeliğin ${ }^{150}$ ekinde yer alan "İşe Giriş/Periyodik Muayene Formu" incelendiğinde, çalışanın laboratuvar bulguları arasında, kan ve idrar testi sonuçlarının da yer aldığı görülmektedir. Bu noktada çalışmamızda daha önce değindiğimiz, işçilerin kolesterol testi için kan ve idrar örnekleri verdiği ve fakat işçilerin bilgisi ve rızası olmadan sifiliz, hamilelik ve orak hücre

1486331 sayılı Kanunun 15. maddesine göre "(1) İşveren; a) Çalışanların işyerinde maruz kalacakları sağlık ve güvenlik risklerini dikkate alarak sağlık gözetimine tabi tutulmalarını sağlar. b) Aşağıdaki hallerde çalışanların sağlık muayenelerinin yapılmasını săglamak zorundadır: 1) İşe girişlerinde. 2) İş değişikliğinde. 3) İş kazası, meslek hastalığı veya sağllk nedeniyle tekrarlanan işten uzaklaşmalarından sonra işe dönüşlerinde talep etmeleri hâlinde. 4) İşin devamı süresince, çalışanın ve işin niteliği ile işyerinin tehlike sınıfına göre Bakanlıkça belirlenen düzenli aralıklarla. (2) Tehlikeli ve çok tehlikeli sınıfta yer alan işlerde çalışacaklar, yapacakları işe uygun olduklarını belirten sağlık raporu olmadan ișe başlatılamaz. (3) (Değișik birinci cümle: 10/9/2014-6552/17 md.) Bu Kanun kapsamında alınması gereken sağlık raporları işyeri hekiminden alınır. 50'den az çalışanı bulunan ve az tehlikeli işyerleri için ise kamu hizmet sunucuları veya aile hekimlerinden de alınabilir. Raporlara itirazlar Sağlık Bakanlığı tarafından belirlenen hakem hastanelere yapılır, verilen kararlar kesindir. (4) Sağlık gözetiminden doğan maliyet ve bu gözetimden kaynaklı her türlü ek maliyet işverence karşılanır, çalışana yansıtılamaz. (5) Sağlı muayenesi yaptırılan çalışanın özel hayatı ve itibarının korunması açısından sağlık bilgileri gizli tutulur".

149 Doktrinde Kim tarafindan haklı olarak belirtildiği üzere bilgisayar teknolojisindeki ilerlemelerin, yüzlerce hatta binlerce genetik mutasyonu aynı anda tespit etmek için daha basit, daha ucuz tekniklerin geliştirilmesine izin vermesi beklenmektedir. Teknoloji geliştikçe ve test maliyeti düştükçe, genetik testler hasta bakımının rutin bir parçası haline gelecektir. Testlerin uygulanması basit ve yeterince ucuz olursa işverenler, bunları genel bir tıbbi tarama programının bir parçası olarak kullanmaya başlayabilir. İşverenler genetik testleri doğrudan kullanmasalar bile işçilerinin tıbbi kayıtlarına erişen işverenler, iş̧̧ilerin genetik özellikleri hakkında bilgi öğrenebileceklerdir, Kim, s. 1512; Aynı yönde Rojas, s. 565; Krumm, s. 496. 
özelliği için test yapıldığı iddiasını içeren Norman-Bloodsaw ve Lawrence Berkeley Laboratuvarı davası akla gelmekte ve sağlık muayenesi sonucunda elde edilen (genetik) bilgiler doğrultusunda ayrımcılığa maruz kalma korkusu yaşayabilecek kişilerin çok da haksız olmayacağ 1 kanaatine varılmaktadır. Yine İş Sağlığ 1 ve Güvenliği Hizmetleri Yönetmeliği ${ }^{151}$ m. 7/1 de söz konusu kanaati destekler niteliktedir. Buna göre “ (1) İşveren ilgili mevzuatta belirlenen süreler saklı kalmak kaydıyla; a) İşyerinde yürütülen iş sağlığ1 ve güvenliği faaliyetlerine ilişkin her türlü kaydı, b) İşten ayrılma tarihinden itibaren en az 15 yıl süreyle çalışanların kişisel sağlık dosyalarını, saklar". Her ne kadar 6331 sayılı Kanunda, sağlık muayenesi yaptırılan çalışanın özel hayatı ve itibarının korunması açısından sağlık bilgilerinin gizli tutulacağı (m. 15/5); İş Sağlığ1 ve Güvenliği Hizmetleri Yönetmeliğinde işyeri sağlık ve güvenlik birimi ile ortak sağlık ve güvenlik birimlerinin çalışanların yürüttüğü işler, işyerinde yapılan risk değerlendirmesi sonuçları ve maruziyet bilgileri ile işe giriş ve periyodik sağlık muayenesi sonuçları, iş kazaları ile meslek hastalıkları kayıtlarının, işyerindeki kişisel sağlık dosyalarında gizlilik ilkesine uyularak saklanmasından sorumlu olduğu (m. 13/1e); yine İşyeri Hekimi ve Diğer Sağlık Personelinin Görev, Yetki, Sorumluluk ve Eğitimleri Hakkında Yönetmeliğinde işyeri hekimleri ve diğer sağlık personelleri için çalışanın kişisel sağlık dosyasındaki bilgileri gizli tutmakla yükümlülügü $(\mathrm{m} .11 / 1, \mathrm{~m} .18 / 1)$ düzenlemiş olsa da genetik bilginin sağlık bilgilerinden daha farklı içerikte olması hususu dikkate alındığında, genetik ayrımcılıkla ilgili ayrı bir yasal düzenleme ihtiyacı devam etmektedir. Ek olarak belirtmek gerekir ki işyerlerinde iş sağlığı ve güvenliğinin sağlanabilmesi için işverenlerin sağlı gözetimi yükümlüğünün çok önemli olduğu yadsınamaz bir gerçektir. Çalışmamızın bu bölümünde, işverenin sağl1k gözetimi yükümlülüğü sonucunda ulaşabileceği genetik bilgilere odaklanılmakla birlikte genetik bilgi, daha önce örnek verdiğimiz Aşkenazi Yahudilerinde olduğu üzere, kişinin bir ırksal ve etnik azınlık gruba dâhil olması sebebiyle de ulaşılabilecek bir bilgidir. Bu durum hem işverenin sağl1k gözetimi yükümlülüğünün genetik bilgiye ulaşmada tek vasıta olmadığı ve genetik ayrımcılık konusu ile işverenin sağlık gözetimi yükümlülüğünün birebir örtüşmediği, dolayısıyla işverenin sağl1k gözetimi yükümlülüğünün geri plana itilmesi sonucuna ulaşılamayacağı hem de genetik ayrımcılık konusunun daha geniş kapsamlı düşünülerek ayrıca düzenlenmesi düşüncesine ulaşmamızı sağlamaktadır. Ek olarak genetik ayrımcılık yasağı düzenlemesi oluşturulurken daha önce değindiğimiz genetik izleme kavramına ve sınırla-

151 RG. 29.12.2012, 28512. 
rına da yer verilmesi özellikle tehlikeli ve çok tehlikeli işyerlerinde işverenin sağlık gözetimi yükümlülüğü bakımından yararlı olacaktır ${ }^{152}$.

İşyerinde genetik tarama yapılmasına izin verilmesi gerekliliği, işverenler tarafından ileri sürülebilir ${ }^{153}$. Bu talebe olumlu cevap ancak, tüm işçiler için makul bir şekilde ortadan kaldırılamayacak veya azaltılamayacak tanımlanmış bir işyeri maruziyeti olduğunda veya tanımlanmış bir genetik mutasyonun, işyerinde kullanılan veya temas edilen maddeye önemli ölçüde duyarlılı̆ $\breve{g}_{1}$ arttırdığının bilinmesi gibi istisnai durumlarda verilebiliir ${ }^{154} . \mathrm{Bu}$ istisnai durumlara ilişkin düzenlemenin de genetik ayrımcılık yasağına ilişkin düzenleme ile birlikte kural altına alınması gerekmektedir.

Genetik ayrımcılık yasağı ile ilgili olarak doktrinde Kim tarafından da işçilerin genetik bilgilerinin kötüye kullanılmasının önüne geçilmesindeki vasıtanın ayrımcılık yasağ 1 düzenlemesinin olmaması gerektiği ileri sürülmektedir ${ }^{155}$. Şöyle ki ayrımcılık karşıtı yasal modele güvenmek, işverenin saikine odaklanılması nedeniyle pratikte önemli zorluklar doğurmaktadır. Ayrımcı düşünceyi kanıtlamanın zorluğu, ayrımcılık yasağı ile ilgili düzenlemelerin ayrımcılığı önlemedeki ve azaltmadaki etkinliğini engellemektedir. Genetik ayrımcılık yasağına ilişkin yasal düzenleme de muhtemelen aynı zorlukları doğuracaktır. Ayrıca motivasyona odaklanan bir ayrımcılık karşıtı model, genetik bilginin kullanılabilirliğini ve göze çarpmasını artırarak işçileri, ironik bir şekilde genetik ayrımcılığa karşı daha savunmasız hale getirebilir ${ }^{156}$. Bu nedenle Kim tarafindan, genetik bilginin gizliliğine ilişkin bir yasal düzenlemenin daha uygun olduğu sonucuna varılmaktadır ${ }^{157}$. Ancak kanaatimizce salt gizliliğe ilişkin yasal düzenleme, genetik bilginin kötüye kullanımının önüne geçmede yeterli olmayacaktır. Genetik ayrımcılık yasağı ile ilgili ayrı bir yasal düzenleme gerekli olduğu gibi genetik ayrımcılık yasağı ile ilgili yasal düzenlemenin, salt hâlihazırda çalışan işçileri değil iş başvurusunda bulunan kişileri de kapsayacak şekilde kural altına alınması

152 Konu hakkında bkz. Carr, s. 11-14.

153 Kim, s. 1541; Doktrinde Krumm'a göre tıbbi açıdan ilgilenilmesi gereken işçiler için genetik test yapılmasına gerek olmadan daha az müdahaleci yollar yeterli olacaktır. $\mathrm{Bu}$ sebeple işverenlere genetik testle ilgili yasak getirilmelidir, Krumm, s. 509 vd.

Kim, s. 1541; Kim'e göre belirtilen koşullar mevcut olsa bile, belirlenmiş genetik güvenlik açıkları için teste tabi tutulup tutulmayacağına ve sonuçların olumlu olması durumunda risklere rağmen çalışmaya devam edip etmeyeceğine işverenin değil iş̧̧inin karar vermesi gerekmektedir, Kim, s. 1542.

156 Kim, s. 1551.

157 Kim, s. 1549 vd. 
gerekmektedir $^{158}$. Aksi halde genetik ayrımcılık nedeniyle işini kaybetmiş kişilerin ayrımcı muameleye maruz kalma tehlikesi artacağı gibi genetik yatkınlığı olan kişilerin çalışma hayatına dâhil olmaları engellenerek genetik alt sınıfın oluşumu hızlanacaktır ${ }^{159}$.

\section{SONUÇ}

Genetik bilimindeki hızlı gelişmeler sayesinde insan sağlığı ile ilgili pek çok olumlu gelişme gerçekleşmektedir. Genetik biliminin ürünü olan genetik testlerin yaygınlaşması ile birlikte her geçen gün daha fazla hayatımıza dâhil olan genetik bilgi kavramının, çalışma hayatında olumsuz etkilerinin olabilme ihtimali de göz ardı edilemeyecek bir gerçektir. İşçi adaylarının veya işçilerinin genetik bilgilerini öğrenen işverenlerin, söz konusu işçi adaylarını genetik bilgileri nedeniyle işe almamaları ve işçilerini de genetik bilgileri nedeniyle işten çıkarabilmeleri durumlarıyla son yıllarda karşılaşılmaktadır. Bu husus İş Hukukunda genetik bilgiye karşı işçilerin korunması gerekliliğini ortaya koymaktadır.

Genetik bilginin kötüye kullanımının önüne geçilmesinde uluslararası hukukta genetik ayrımcılık yasağı ile ilgili düzenlemeler kural altına alınmış hatta ülkemiz de konu ile ilgili en önemli uluslararası sözleşme olan Biyoloji ve T1bbın Uygulanması Bakımından İnsan Hakları ve İnsan Haysiyetinin Korunması Sözleşmesi: İnsan Hakları ve Biyotıp Sözleşmesi'ni imzalayarak iç hukuka dâhil etmiştir. Ancak genetik bilgiye erişimin gittikçe kolaylaşacak ve hızlanacak olması gerçeği göz önüne alındığında özellikle İş Hukuku bakımından, genetik ayrımcılık yasağı ile ilgili ayrı bir yasal düzenleme ihtiyacı olduğu sonucuna varılmaktadır. Konu ile ilgili Amerikan Hukuku önemli bir örnek teşkil etmektedir. Amerika'da genetik bilgi nedeniyle işe alınmama ve işten çıkarılma olaylarının fazlaca yaşanması ile birlikte federe devletler düzeyinde genetik ayrımcılık yasağı düzenlenmiş ve fakat yeterli koruma olmadığ 1 fark edildiğinde, federal düzeyde GINA yürürlüğe girmiştir. İş Hukukunda genetik ayrımcıllğı yasaklayan ve işverenlerin işçilerin genetik bilgilerini edinmelerine kısıtlama getiren söz konusu Kanun, İş Hukukunda genetik ayrımcılık yasağ 1 düzenlemesi oluşturulurken kanaatimizce incelenmesi ve göz önünde bulundurulması gereken niteliktedir.

Türk Hukuku açısından inceleme yapıldığında, ayrımcılık yasağı düzenlemesi sebebiyle İş Hukukunda da genetik ayrımcilığın yasak olduğu ve ek olarak genetik bilginin kişisel veri olduğu dikkate alındığında, kişisel

Carr, s. 8.

159

Carr, s. 8. 
verilere ilişkin korumaya genetik bilginin de dahil olduğu bilgisine ulaş1maktadır. Bununla birlikte genetik bilginin kötüye kullanımının potansiyel tehlikeleri düşünüldüğünde İş Hukukunda genetik ayrımcılık yasağının, GINA'da olduğu üzere, ayrı bir yasal düzenleme ile kural altına alınması gerekmektedir. Zira genetik ayrımcılığa karşı işçilerin ayrıca korunmayıp, genetik ayrımcılığın yaygınlaşması durumunda olumsuz sonuçları toplum için geçerli olacaktır. Olumsuz genetik bilgiye sahip olan işçileri korumamak, o işçilerin olumsuz genetik durumlarına ek olarak azalan istihdam firsatı riskini yaşamalarına ve bu durumun topluma yayılmasıyla birlikte toplumda genetik alt sınıfın oluşmasına neden olacaktır ${ }^{160}$. ILO'nun 2007 tarihli Raporunda da ifade edildiği üzere genetik bilgi nedeniyle diferansiyel muamelelerin nesnel, makul, uygun ve orant1l olmas1 gerekmektedir ${ }^{161}$.

\footnotetext{
160 Kim, s. 1541.

161 ILO - Uluslararası Çalışma Ofisi Raporu, s. 49.
} 


\section{KAYNAKÇA}

Ajunwa, Ifeoma: "Genetic Data and Civil Rights", Harvard Civil RightsCivil Liberties Law Review, Cilt 5, Say1 1, 2016, ss. 75-114.

Akıncı, Ayşe Nur: Avrupa Birliği Genel Veri Koruma Tüzüğü’nün Getirdiği Yenilikler ve Türk Hukuku Bakımından Değerlendirilmesi - Çalışma Raporu - 6. T.C. Kalkınma Bakanlığı Yayın No: 2968, Haziran 2017, http://www.bilgitoplumu.gov.tr/wp-content/uploads/2017/07/AB Veri_Koruma_Tuzugu.pdf, (10.06.2020).

Akyiğit, Ercan: İş Hukuku, 11. Basım, Seçkin Yayıncılık, İstanbul, 2016.

Bakırcı, Kadriye: "Eşitlik Kurulu Kanunu ile Anayasa ve İş Kanunu'nun İlgili Hükümleri Üzerine Bir Değerlendirme", (Ed. Necdet Basa, Sema Uçakhan Güleç), Emeğin Hukuku Kurultayı 2, Türkiye Barolar Birliği Yayın1, Ankara, 2017, ss. 65-92.

Baysal, Ulaş: "İşverenin Eşit Davranma Borcu ve İş Sözleşmesinin Feshinde Uygulanması", Legal İş Hukuku ve Sosyal Güvenlik Hukuku Dergisi, Cilt 7, Say1 25, 2010, ss. 59-99.

Billings, Paul R. ve diğerleri: "Discrimination as a Consequence of Genetic Testing", Am. J. Hum. Genet., Cilt 50, 1992, ss. 476-482.

Blanck, Peter/Paor, Aislıng De: "US Legislative and Policy Response: Some Historical Context to GINA", Genetic Discrimination Transatlantic Perspectives On The Case For a European-Level Legal Response, (Ed. Gerard Quinn, Aisling de Paor and Peter Blanck), Routledge, New York, 2015, ss. 97-113.

Bozkurt Gümrükçüoğlu, Yeliz: "İş İlişkisinde Kişisel Verilerin Korunmasına İlişkin Sorunlar ve Kişisel Verilerin Korunması Kanunu", İş Hukukunda Yeni Yaklaşımlar (Ed. Kübra Doğan Yenisey, Seda Ergüneş Emrağ), Beta Yayınc1lık, İstanbul, 2017, ss. 19-101.

Carr, Susannah: "Invisible Actors: Genetic Testing and Genetic Discrimination in the Workplace", University of Arkansas at Little Rock Law Review, Cilt 30, Say1 1, 2007, ss. 1-18.

Çelik, Nuri: "İşçilerin İşten Çıkarılmalarında İhbar ve Kıdem Tazminatları Dışında İsteyebilecekleri Tazminatlara İlişkin Sorunlar", Legal İş Hukuku ve Sosyal Güvenlik Hukuku Dergisi, Cilt 4, Sayı 14, 2007, ss. $5-12$.

Çelik, Nuri/Caniklioğlu, Nurşsen/Canbolat, Talat: İş Hukuku Dersleri, Yenilenmiş 32. Bas1, Beta Yayıncılık, İstanbul, 2019. 
Demir, Fevzi: "İşverenin Eşit İşlem Yapma Borcu ve Ayrım Yasağı Tazminatının Diğer Tazminatlarla İlişkisi”, Legal Legal İş Hukuku ve Sosyal Güvenlik Hukuku Dergisi, Cilt 11, Sayı 41, 2014, ss. 15-25.

Doğan, Sevil: "Türk İş Hukukunda Eşitlik İlkesinin Anlamı", Türkiye Adalet Akademisi Dergisi, Say1 9, 2012, ss. 177-205.

Doğan Yenisey, Kübra: "İş Kanununda Eşitlik İlkesi ve Ayrımcılık Yasağı", Çalışma ve Toplum, Cilt 4, Sayı 11, 2006, ss. 63-81.

Doğan Yenisey, Kübra: "Eşit Davranma İlkesinin Uygulanmasında Metodoloji ve Orantılılık". Legal İş Hukuku ve Sosyal Güvenlik Hukuku Dergisi, Cilt 2, Say1 7, 2005, ss. 974-1003, (Metodoloji).

Ekmekçi, Ömer/Yiğit, Esra: Bireysel İş Hukuku Dersleri, On İki Levha Yayıncılık, İstanbul, 2020.

Equality At Work: Tackling The Challenges, Global Report Under The Follow-Up To The ILO Declaration On Fundamental Principles And Rights At Work, International Labour Conference 96th Session 2007 Report I (B). https://www.ilo.org/wcmsp5/groups/public/--dgreports/dcomm/webdev/documents/publication/wcms_082607.pdf, (09.05.2020).

Ertürk, Şükran: İş İlişkisinde Temel Haklar, Seçkin Yayıncılık, Ankara, 2002.

Ertürk, Şükran/Gürsel, İlke: “İş Hukukunda Eşit Davranma İlkesi”, Prof. Dr. Sarper Süzek'e Armağan C. I, Beta Yayıncılık, İstanbul, 2011, ss. 425-458.

Gardner-Hopkins, James Desmond K: "Unemployable Genes: Genetic Discrimination in the Workplace", Auckland University Law Review, Cilt 9, Say1 2, 2001, ss. 435-469.

Genetik Terimler Sözlüğü, http://www.thd.org.tr/thdData/Books/723/ genetik-terimler-sozlugu.pdf, (02.04.2020).

Gürsel, İlke: İş̧̧inin Kişisel Verilerinin Korunması Hakkı, Adalet Yayınevi, Ankara, 2016.

Gürsel, İlke: "Kişisel Verilerin Korunması Hakkının İşçi ve İşveren İlişkilerine Etkileri”, Legal İş Hukuku ve Sosyal Güvenlik Hukuku Dergisi, Cilt 50, 2016, ss. 763-848, (Etki).

Hellman, Deborah: "What Makes Genetic Discrimination Exceptional", American Journal of Law \& Medicine, Cilt 29, Say1 1, 2003, ss. 77116. 
İnceoğlu, Sibel: "Türk Anayasa Mahkemesi ve İnsan Hakları Avrupa Mahkemesi Kararlarında Eşitlik ve Ayrımcılık Yasağı", Çalışma ve Toplum, Cilt 4, Say1 11, 2006, ss. 45-62.

Kandemir, Murat/Yardımcıoğlu, Didem: "İş Hukukunda Eşitlik İlkesi", Dicle Üniversitesi Hukuk Fakültesi Dergisi, Cilt 19, Sayı 30-31, 2004, ss. 1-44.

Keser, Hakan: "4857 Sayılı İş Kanununa Göre İşverenin İş Sözleşmesi Yapma ve İş İlişkilerinde Eşit İşlem Yapma Yükümlülükleri ve Bunlara Aykırı Davranılması Durumunda Karşılaşacağı Yaptırımlar”, Yargı̨̧ Resul Aslanköylü'ye Armağan, Kamu-İş, Cilt 7, Sayı 3, 2004, ss. 1-38.

Kim, Pauline T: "Genetic Discrimination, Genetic Privacy: Rethinking Employee Protections for a Brave New Workplace", Northwestern University Law Review, Cilt 96, Say1 4, 2002, ss. 1497-1552.

Kim, J. Rosel/Salman, Shahad/Joly, Yann: "The Use of Genetic İnformation Outside of The Therapeutic Health Relationship: An İnternational Perspective", Genetic Discrimination Transatlantic Perspectives On The Case For a European-Level Legal Response, (Ed. Gerard Quinn, Aisling de Paor and Peter Blanck), Routledge, New York, 2015, ss.68-94.

Krumm, Jennifer: "Genetic Discrimination: Why Congress Must Ban Genetic Testing in the Workplace", Journal of Legal Medicine, Cilt 23, Say1 4, 2002, ss. 491-522.

Küçük, Damla: "Sigortacılıkta Haksız Ayırımcı Uygulamalar Bağlamında 'Verimli Sinıflandırma' ve 'Adil Sınıflandırma' Yaklaşımlara Kısa Bir Bakış", Uluslararası Akademik Araştırmalar Kongresi, 16-17-18 Eylül 2019 Bolu, Sempozyum Özet Kitapçı̆̆ı, Makale ID: 92, https://kongre.akademikiletisim.com/files/icar2019/icar_ozet_kitapcigi. pdf, ss. 331-337.

Küzeci, Elif: "Genetik Ayrımcılık Yasağı, Yeditepe Üniversitesi Hukuk Fakültesi Dergisi, Cilt XV, Sayı 1, 2018, ss. 89-132.

Küzeci, Elif: Kişisel Verilerin Korunması, Yenilenmiş ve Gözden Geçirilmiş 3. Bask1, Turhan Kitabevi, Ankara, 2019, (Kişisel Veri).

Manav, A. Eda: "İş İlişkisinde İşçinin Kişisel Verilerinin Korunması", Gazi Üniversitesi Hukuk Fakültesi Dergisi, Cilt XIX, Sayı 2, 2015, ss. 95136.

Miller, Paul Steven: "Genetic Discrimination in the Workplace", Journal of Law, Medicine and Ethics, Cilt 26, Say1 3, 1998, ss. 189-197. 
Mollamahmutoğlu, Hamdi/Astarlı, Muhittin/Baysal, Ulaş: İş Hukuku, Gözden Geçirilmiş ve Genişletilmiş 6. Bası, Turhan Kitabevi, Ankara, 2014.

Murray, Thomas H.: "Is Genetic Exceptionalism Past Its Sell-By Date? On Genomic Diaries, Context, and Content", The American Journal of Bioethics, Cilt 19, Say1 1, 2019, ss. 13-15.

Nazlı, Seçkin: “İş Kanunu'nda Düzenlenen Eşit Davranma İlkesi ve Uygulama Sorunları Üzerine Değerlendirmeler", İstanbul Üniversitesi Hukuk Fakültesi Mecmuası (Prof. Dr. Fevzi Şahlanan'a Armağan), Cilt I, Özel Say1, 2016, ss. 571-586.

Nemeth, Patricia/Bonnette, Terry W: "Genetic Discrimination in Employment”, Michigan Bar Journal, January 2009, ss. 42-45.

Odaman, Serkan: "Ayrımcılık Tazminatının Diğer Tazminatlarla Birlikte Mevcudiyeti Üzerine Görüşler”, Sicil İş Hukuku Dergisi, Sayı 14, 2009, ss. 77-83.

Okur, Zeki: “Türk İş Hukukunda İşçinin Kişisel Verilerinin Korunması Hakkı”, İş Dünyası ve Hukuk: Prof. Dr. Tankut Centel'e Armağan, İstanbul Üniversitesi Yayınları, İstanbul, 2011, ss. 368-408.

Olick, Robert S.: "Genetic Discrimination in the Workplace After GINA", Genetic Discrimination Transatlantic Perspectives On The Case For a European-Level Legal Response, (Ed. Gerard Quinn, Aisling de Paor and Peter Blanck), Routledge, New York, 2015, ss. 128-140.

Paor, Aisling de/Lowndes, Noel: "Tracing The History, Evolution and Future Orientation of Genetic Science and Technology", Genetic Discrimination Transatlantic Perspectives On The Case For a European-Level Legal Response, (Ed. Gerard Quinn, Aisling de Paor and Peter Blanck), Routledge, New York, 2015, ss. 11-35.

Paor, Aisling de/Ferri, Delia: "Regulating Genetic Discrimination in the European Union", European Journal of Law Reform, Cilt 17, Say1 1, 2015, ss. 14-32.

Prince, Anya/Waterstone, Michael: "The Genetic Information Nondiscrimination Act (GINA) 2008", Genetic Discrimination Transatlantic Perspectives On The Case For a European-Level Legal Response, (Ed. Gerard Quinn, Aisling de Paor and Peter Blanck), Routledge, New York, 2015, ss. 114-127. 
Protection of Workers' Personal Data - ILO Code of Practice, https://www.ilo.org/public/libdoc/ilo/1997/97B09_118_engl.pdf, (01.05.2020)

Rojas, Hugo: "Labor Law And Genetic Discrimination in Chile", Florida Journal of International Law, Cilt 16, Say1 3, 2004, ss. 561-578.

Senyen-Kaplan, E. Tuncay: Bireysel İş Hukuku, Yenilenmiş 10. Bask1, Gazi Kitabevi, Ankara, 2019.

Senyen Kaplan, E. Tuncay: İş Hukukunda Eşitlik İlkesi ve Ayrımcılık Yasağ1, Türkiye Barolar Birliği Dergisi, Özel Say1, 2017, ss. 225-268. (Eşitlik)

Smith, George P. II/Burns, Thaddeus J.: "Genetic Determinism or Genetic Discrimination", Journal of Contemporary Health Law and Policy, Cilt 11, Say1 1, 1994, ss. 23-62.

Sur, Melda: "İş İlişkisinde Eşitlik İlkesi ve Ayrımcılık Yasağı”, Sicil İş Hukuku Dergisi, Sayı 37, 2017, ss. 33-51.

Süzek, Sarper: İş Hukuku, Yenilenmiş 18. Baskı, Beta Yayıncılık, İstanbul, 2019.

Süzek, Sarper: "İşverenin Eşit Davranma Borcu”, Sicil İş Hukuku Dergisi, Say1 12, 2008, ss. 34-38, (Eşit Davranma).

Spaak, Torben: “Genetic Discrimination”, Minn. J.L. Sci. \& Tech., Cilt 7, 2005-2006, ss. 639-656.

Şen, Murat: "Gen Analizlerinin İş Hukuku Alanında Kullanımı”, Marmara Üniversitesi Hukuk Fakültesi Hukuk Araştırmaları Dergisi, Cilt I, Sayı 1, 2012, ss. 129-144.

Taylor, Mark J.: "Data Protection, Shared (Genetic) Data and Genetic Discrimination", Medical Law International, Cilt 8, Say1 1, 2006, ss. 51-78.

Tuncay, A. Can: İş Hukukunda Eşit Davranma İlkesi, Fakülteler Matbaası, İstanbul, 1982.

Tunçomă̆, Kenan/Tankut, Centel: İş Hukukunun Esasları, 9. Baskı, Beta Yayıncıl1k, İstanbul, 2018.

Ulucan, Devrim: "Eşitlik İlkesi ve Pozitif Ayrımcılık Yasağı. DEÜHFD. C. 15, Özel Say1, 2013, ss. 369-383.

Ünal, Canan: İş Hukukunda Yaş Ayrımcılığı, On İki Levha Yayıncılık, İstanbul, 2018. 
Ünal, Canan: "Yaş Ayrımcıllı̆ı Kapsamında İş Sözleşmesinin Sona Ermesinde Yaş ve Emekliliğin Değerlendirilmesi", İş Hukukunda Yeni Yaklaşımlar, (Ed. Kübra Doğan Yenisey, Seda Ergüneş Emrağ), Beta Yayınc1l1k, İstanbul, 2017, ss. 313-377, (Emeklilik).

Ünal, Canan: "İş Sözleşmesinin Kurulmasında Sağlığa İlişkin Veriler", İş Hukukunda Genç Yaklaşımlar III, (Ed. Tankut Centel), On İki Levha Yayınc1l1k, İstanbul, 2018, ss. 261-318, (Sağlık)

Yıldız, Gaye Burcu: İşverenin Eşit İşlem Yapma Borcu, Yetkin Yayıncılık, Ankara, 2008.

Yıldız, Gaye Burcu: "İş Sözleşmesinin Feshinde Eşit İşlem Yapma Borcu ve Ayrımcılık Yasağı”, Prof. Dr. Ali Güzel'e Armağan, C. I, İstanbul, 2010, ss. 837-871, (Ayrımc1lik).

https://ec.europa.eu/justice/article-29/documentation/

opinionrecommendation/files/2004/wp91_en.pdf, (04.03.2020).

http://www.msnbc.com/msnbc/aol-backtracks-after-distressed-babies-flap, (10.03.2020).

http://www.geneticfairness.org/index.html, (10.04.2020).

https://www.tbmm.gov.tr/kanunlar/k5013.html, (12.04.2020).

https://rm.coe.int/CoERMPublicCommonSearchServices/DisplayDCTMCon tent?documentId $=090000168007 \mathrm{cf9} 8,(12.04 .2020)$.

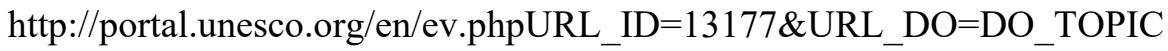
\&URL_SECTION=201.html, (16.04.2020).

https://www.eeoc.gov/eeoc/statistics/enforcement/genetic.cfm, (22.04.2020).

https://www.eeoc.gov/eeoc/, (23.04.2020).

https://www.23andme.com/en-eu/genetic-science/, (23.04.2020).

https://www.help.senate.gov/about, (26.04.2020).

https://gdpr-info.eu/, (29.04.2020).

https://eur-lex.europa.eu/legal-content/en/TXT/?uri=CELEX\%3A31995 L0046, (17.06.2020).

https://kisiselveri.com/9546ec-turkce, (17.06.2020). 